\title{
Szemafor hát!
}

\author{
Szeteli Anna \\ PTE Nyelvtudományi Tanszék \\ Gocsál Ákos \\ MTA Nyelvtudományi Intézet, Fonetikai osztály \\ Alberti Gábor \\ PTE Nyelvtudományi Tanszék
}

\begin{abstract}
Összefoglaló
Vizsgálatunkban sikerült a szóbeliségben leggyakoribb, szélsőségesen multifunkcionális magyar diskurzusjelölőnek, a hát-nak öt, páronként szignifikánsan eltérő prozódiai jellemzőkkel bíró változatát elkülöníteni. Egészen pontosan a következő prozódiai jellemzők [I, I', p] hármasáról van szó, ahol I a hát hangsor kiejtésének hosszát jelöli, p az eközben változó alapfrekvencia-értékekböl adódó dallamosságot, l' pedig a hát-ot követő szünet hosszát. Eredményeink nem állnak ellentétben a Dér és Markó szerzőpároséival (Dér-Markó 2017), akik alapvetően fordulópozíciók szerint különítenek el funkciókat, míg a mi legfőbb álításunk az, hogy csak fordulókezdő mondatéli hát-funkcióból szignifikánsan elkülöníthető négy-, sőt tulajdonképpen ötféle: a „határozott”, a „bizonytalan”, az „aggodalmas” és kétféle „incselkedő”; tárgyalunk továbbá egy mondatzáró „nyomatékosító” hát-ot is. Az által, hogy Dér és Markó ezeket el nem különítetten értékelte statisztikailag, semlegesíthette a különbségeiket. A mi elsődleges célunk viszont éppen e különbségekkel volt kapcsolatos: azt kívántuk kísérletesen igazolni, hogy a fordulókezdő hát az Alberti (2016) által felvetett szemaforszerű viselkedést mutatja.
\end{abstract}

Kulcsszavak: diskurzusjelölő, diskurzusreprezentáció, formális pragmaszemantika, prozódiai jellemzők

\section{Bevezetés: hát vágjunk bele!}

Vizsgálatunkban sikerült a szóbeliségben leggyakoribb, szélsőségesen multifunkcionális magyar diskurzusjelölőnek, a hát-nak (lásd pl. Schirm 2007-2008: 187, ill. 189, 193, 197; Dér-Markó 2007) elkülöníteni öt páronként szignifikánsan eltérő prozódiai jellemzőkkel bíró változatát. Egészen pontosan a következő vokális tényezők [l, I', p] hármasáról van szó, ahol I a hát hangsor kiejtésének hosszát jelöli, p az eközben változó alapfrekvencia-értékek szórását, l' pedig a hát-ot követő (kitöltetlen vagy kitöltött) szünet hosszát.

Eredményeink nem állnak ellentétben a Dér és Markó szerzőpároséival (DérMarkó 2017), mivel ők alapvetően fordulópozíciók szerint különítenek el funkciókat, míg a mi legfőbb állításunk az, hogy csak fordulókezdő mondatéli hát-funkcióból szignifikánsan elkülöníthető négyféle: a „határozott”, a „bizonytalan”, az „aggodalmas” és az „incselkedő” kétféle stratégiával; tárgyalunk továbbá egy mondatzáró „nyomatékosító” hát-ot. Az, hogy Dér és Markó ezeket el nem különítetten értékelte 
statisztikailag és vetette össze más, minden bizonnyal hasonlóan kevert funkciókkal, olyan, mintha nem egyes borokat próbálnánk az ízük alapján elkülöníteni, hanem összeöntenénk egy-egy pincészet összes, eltérő karakterű borát, semlegesítve a különbségeiket. ${ }^{1}$ Elsődleges célunk éppen e különbségekkel volt kapcsolatos; azt kívántuk kísérletesen igazolni, hogy a fordulókezdő hát az Alberti (2016) által felvetett szemaforszerü viselkedést mutatja. Ahogy a mozdony vezetőjének sem a szemafor puszta megpillantása nyújt fontos eligazítást (az önmagában csupán annyit jelez, hogy most fontos eligazítás következik), hanem annak állása. Azaz a három beszédhang szekvenciája önmagában nem hordoz pragmaszemantikai kontribúciót, hanem az arra illesztett prozódia üzen valami fontosat a címzettnek: „könnyen vagy nehezen emészthető, vagy ... tartalomra készülj!” - a pontsor helyére írható jelzőkről kíván e tanulmány beszámolni, a teljesség igénye nélkül. Ezzel kapcsolatban fontos megjegyeznünk, hogy esetünkben nem csak e tanulmány terjedelme, hanem az elméleti munka mellett végzett ismételt méréses kísérlet hossza is határt szabott a vizsgálható funkciók számának tekintetében. Ezáltal támaszkodunk tanulmányunkban - már csak a kísérlet pilot-jellegénél fogva is mindössze Alberti (2016) kategóriáira, az összefoglalás előtti fejezetet szánva további kutatási irányok kijelölésére.

Ami tanulmányunk tartalmát illeti, a 2. szakaszt az általunk elvégzett kísérletsorozat bemutatásának szenteljük. Itt ismertetjük, hogy milyen teszthelyzet révén különítettünk el négyféle fordulóindító hát-ot, eltérve a Dér és Markó tanulmányának bevezetésében felsorolt 12 típustól (Dér-Markó 2017), illetve az abból általuk kiválasztott négy típustól. Itt számolunk be a statisztikai elemzések eredményeiről is.

A 3. szakasz az eredmények pragmaszemantikai interpretációjával szolgál. Amellett érvelünk, hogy a hát magyar szakirodalmában eddig alkalmazott leíró apparátust cizellálni érdemes egy finomabb (diskurzus-)reprezentációs szisztémával, amelyik rekurzív leírását nyújtja a hát diskurzusjelölővel módosított megnyilatkozás feladójának az üzenetbe éppen ilyetén módon berejtett közlésébe arról, hogy milyen hipotézisei (B: belief), vágyai (D: desire) és szándékai (I: intention) vannak az üzenetbe foglalt információra nézve. Az imént a rekurzió alatt azt értettük, hogy a feladó a címzett hipotéziseiről, vágyairól és/vagy szándékairól (azaz BDI-profiljáról / intenzionális profiljáról) is információt nyújt, illetve annak az éppen őrá vonatkozó BDI-profiljáról - vagyis a feladó a beszélgetőtárs szemével is megpróbálja nézni önmagát. Alberti (2016)-ot követve a ReALIS elméleti keretében elemzünk, amelynek aktuális verzióját célorientáltan felvázoljuk, elhelyezve a formális diskurzusreprezentációs elméletek körében. Előrebocsátjuk, hogy a hát-funkciókat a diskurzusjelölők multifunkcionalitásáról felállított poliszémiaelgondolás keretében fogjuk megragadni (Fischer 2006: 13-14), ami azon a kézenfekvő feltételezésen alapul,

\footnotetext{
${ }^{1}$ Félreértés ne essék, a hasonlat nem pejoratív. Releváns tudományos kérdés az is, hogy van-e olyan közös prozódiai jellemzője az összes fordulóindító hát-nak, ami a „portfólióban” is megmutatkozik. És igen! Mint azt Dér-Markó (2017: 8-9) megállapítja, a hossz alapján az átlagos fordulóindító hát a fordulóban köztes pozícióban megjelenő, „késleltető” hát-tól szignifikánsan elkülöníthető, ha más, általuk vizsgálttól nem is. Megjegyezzük, hogy ezt az eredményt a mi elméleti megközelítésünk is alátámasztja majd. Dérék tehát - visszatérve a fenti hasonlatra - pincészeteket próbálnak összehasonlítani ízviláguk közös jellemzőit firtatva, míg mi egy pincészeten belül különítjük el a borokat, ízviláguk egyediségét keresve.
} 
hogy egyazon forma számos különböző, de egymással kapcsolatban lévő és egymásból levezethető interpretációval bír. Ez utóbbira teszünk kísérletet, mármint a jellemzett hát-funkciók kapcsolati hálózatának felállítására, egyúttal finomítva/relativizálva a poliszémia-fogalmat.

Ahogyan azt már említettük, a 4. szakaszban a hát további néhány funkcióját kíséreljük megragadni, kijelölve néhány érdekes jövőbeli kutatási témát.

Az 5. szakasz pedig rövid összefoglalásként szolgál.

\section{Hát mit is teszteltünk?}

Jelen szakaszban számolunk be egyrészt Dér és Markó a hát diskurzusjelölőt érintő kísérletének eredményeiről (Dér-Markó 2017), másrészt bemutatjuk saját kísérletünket, és ismertetjük annak eredményeit. A két kutatás mind módszertanilag, mind a kiválasztott hát-funkciók tekintetében eltér egymástól, azonban bizonyos kategóriák tekintetében mutatkoznak átfedések.

\subsection{A tesztelésre kiválasztott hát-funkciók}

Dér-Markó (2017) a hát diskurzusjelölőt fokozottan multifunkcionális jelölőként határozzák meg, ami abban nyilvánul meg, hogy az „(...) elem egyazon aktuális használatában több diskurzusszintet érintő feladatokat lát el, és ez a jellemző rá általában" (Dér-Markó 2017: 105). A szerzők Fischert követik abban, hogy a diskurzusjelölő poliszém rendszert kiépítve, egymással összefüggő interpretációkkal bír (Fischer 2006: 13-14). Méréseiket a BEA spontán beszéd adatbázisból vett mintáin végezték, a 23 budapesti beszélő (11 nő és 12 férfi) átlagéletkora 47,13 év volt.

Noha Dér-Markó (2017) eredendően 12 különféle hát-funkcióval számol többek között Schirm (2011) és Dér (2015) addigi leírásainak tapasztalatait összegezve, végül arra jutnak, hogy csak négy megfelelően mérhető funkció marad.

A következő szempontok alapján szükítik le vizsgálatukat négy funkcióra: (i) ezeket tekinthetjük „igazán lényegesnek” (ami nehezen megragadható kritérium), (ii) megbízhatóan (notóriusan jelentkező átfedések nélkül) el lehet különíteni őket a többitől, (iii) nem jellemzi őket konnotálódási hajlam, és (iv) példányaikat a vizsgált korpuszban biztonságosan lehet azonosítani. Az azonosítás biztonságos alapját végül három funkció esetében az a kifejezetten formai szempont jelenti, hogy fordulóindító, fordulózáró vagy fordulóközi pozíciót foglal-e el az adott hát-előfordulás. Hármukhoz végül egy értékelő funkciót vettek hozzá, amelyet csak úgy tudunk koherens tagnak tekinteni, ha formálisan így ragadjuk meg (a szerzők egyetlen példájából kiindulva): egyszerre fordulóindító és -záró funkciójú előfordulás, egyetlen (bár esetleg sokszorosan összetett) mondatból álló fordulóban.

Dér és Markó kimutatta (Dér-Markó 2017: 110), hogy a késleltető funkciójú, fordulóközi használat szignifikánsan hosszabb a többinél, azonban egyéb, (i) a hát diskurzusjelölő hosszával, (ii) a diskurzusjelölőt követő szünet hosszával, illetve (iii) alaphangmagassággal kapcsolatos hipotéziseiket nem tudták igazolni. Nem állítható, hogy e hipotézisek helytelenek volnának, mert a kollokációk és a multifunkcionális minták kiszürésének következtében a minta annyira lecsökkent, hogy részint meg sem felelt további tesztek elvégzéséhez. 
Alaphang-frekvenciával kapcsolatos hipotéziseik igazolását az lehetetlenítette el, hogy sok esetben nem tudták kinyerni a szükséges frekvenciaadatokat egyidejü beszéd, illetve irreguláris zönge jelenléte miatt. Mindenesetre rámutattak a tendenciára, hogy a diskurzusjelölőt követő szegmensek alaphang-frekvenciája alacsonyabb, mint a jelölőé.

Nyitottnak tekinthetjük tehát a pragmaszemantikai szempontok alapán felállítandó hát-funkciók kérdését, ahol szükség van olyan új gondolatok termékenyítő hatására, mint a BDI alapú intenzionális profilok bevezetése. Gyakorlatilag a hát-ot kimondó feladó hipotéziseinek, vágyainak, szándékainak bázisán véljük megvalósíthatónak a funkciók egyértelmű, megbízható, átfedésektől és összemérhetetlen szempontoktól megtisztított meghatározását.

\subsection{Egy egyszeri húszéves egyetemista lány szavai és gondolatai}

Adatközlőinket az alábbi instrukciókkal láttuk el:

„Azt fogjuk majd kérni, hogy Anti és Bea alábbi párbeszédében olvassa fel, pontosabban játssza el Bea szerepét! Azért említjük az eljátszást, mert fontos a kísérlet szempontjából, hogy ne monoton felolvasási hangsúlyt alkalmazzon (ez az idevágó szakirodalom szerint hamis képet ad), hanem élje át a felvázolt szituációt a megadott háttértudás alapján, és úgy adja elő a szóban forgó pár mondatot. Arra kérjük, hogy minden leírt szót a megadott szórend szerint mondjon el, mert nagyon fontosak számunkra a finom részletek. Az írásjeleket viszont nem tettük ki Bea szövegében, mert az is nem kívánatos befolyásoló tényező."

Az instrukció folytatásában utalunk a BDI alapú intenzionális profilra:

„Az eljátszás előtt gondosan olvassa át mind a dialógust, mind a háttérbeli gondolatokat. A háttértörténetet ismerni kell ebben a kísérleti sémában. Anti és Bea húsz év körüli egyetemista szerelmespár. Egy éve minden hétvégén elmennek egy moziba, és szigorúan felváltva választanak filmet. Meglehetősen jól ismerik már egymás ízlését ezen a téren (és a tesztek annyiból nem függetlenek, hogy a szereplők ízlését végig egységesen kezeljük). Ezúttal Beán a választás sora. Most éppen abban a pillanatban halljuk őket, amikor Bea már végignézte a mozi kínálatát és meghozta a döntését, de még nem mondta el Antinak, aki kíváncsian várja az „eredményhirdetést”. Három film verseng:

- $\quad$ egy klasszikusnak ígérkező angol krimi,

- $\quad$ egy malackodó poénokat sejtető amerikai vígjáték,

- $\quad$ egy nyomasztónak tűnő izlandi dráma.

Tudni kell még, hogy mind Anti, mind Bea hétről hétre azon a kézenfekvő módon hoz döntést, hogy némileg szeretné kihasználni a választási esélyt, de semmiképpen nem akar rosszat partnerének sem."

Ötféle hát-funkció prozódiai jellemzőit kívántuk feltárni négy tesztdialóguson keresztül. Mind a négynek a tesztlapja azzal kezdődik, hogy ismét Bea információállapotát taglaljuk, annak számunkra releváns intenzionális profilját meghatározva. 
„Ami Bea gondolatait illeti a megszólalása pillanatában, ez a lényeg: Ebben a teszthelyzetben [lassan áttérünk az 1.1. teszt részletezésére, amit a 2.2.1. szakaszban mutatunk be] Bea biztos benne, hogy az egyetlen jó döntést hozta meg, amitöl különbözőt minden bizonnyal Anti sem tudna elképzelni. Ez az indoklásból kiderül, ami a színtiszta igazságot tartalmazza, minden csúsztatás, udvariaskodás vagy képmutatás nélkül."

Majd jön a dialógus, amelynek Anti-szerepét az egyik kísérletvezető olvasta fel, miután a másik kísérletvezető előtte ismertette Bea gondolatait. Megjegyzendő, hogy ezt megelőzően az adatközlők 5-10 percen keresztül tanulmányozhatták a tesztlapot, hogy ne felolvasást produkáljanak, hanem átélhessék Bea intenzionális profilját: érzéseit, vágyait, szándékait, sejtéseit. ${ }^{2}$ Ezen a ponton ismertetjük, hogy valamennyi adatközlőnk 20 év körüli pécsi egyetemista lány volt a középiskolait valamelyest meghaladó nyelvtudományi ismeretekkel, de a jelentéstanban és/vagy a pragmatikában nem mélyedtek el; egymással nem tárgyalhatták meg elöre a tesztfeladatokat, önként vettek részt a kísérletben, és nem kaptak pénzt a részvételért.

\subsubsection{A határozott hát}

Lássuk hát a tesztdialógust, ahogyan az adatközlők olvashatták, majd - legalábbis Anti szavait - hallhatták!

Anti: Na, melyik filmet választottad?

Bea: Hát a krimit

Az mindkettőnknek be szokott jönni

Az ízléstelen vígjátékokból a múltkor végképp elegünk lett a nyomasztó északi drámákért pedig még én sem rajongok bár én alapjában véve kedvelem a komolyabb müfajokat

$A z$ 1.1. teszt egy olyan funkciót volt hivatott megjeleníteni, amire így utalhatunk: „a határozott hát”. Megjegyezzük, hogy az adatközlöket nem befolyásoltuk ezzel a megnevezéssel, ők csak Bea azon gondolatairól „értesültek”, hogy a lány biztos abban, hogy jó döntésre jutott, amikor a krimit választotta, és hogy Anti se döntött volna másképpen.

Érdemes ezen a ponton végiggondolni tesztdialógusaink azon sajátosságát, miszerint a különféle hát-funkciókat történetesen egy performatív - austini értelemben végrehajtó (exercitív) - beszédaktust megvalósító mondatba helyeztük (Austin 1975 [1962]: 150): a választásról szóló döntés kimondásával megvalósul a választás ténye, az „ítélethirdetés”, így megkonstruálódik annak igaz volta is, kizárva a hamis igazságértéket. A (2) példával azt szemléltetjük, hogy ez a tulajdonság nem kötődik szükségszerüen a tanulmányozott hát-funkcióhoz, amit az alapján azonosíthatunk, hogy a hát-ot kimondó beszédpartner (jelen esetben Vali) intenzionális

${ }^{2}$ A profil intenzionális karaktere arra utal, hogy a képzeletbeli Bea által kreált lehetséges világok egyes szegmenseit idézzük fel: például annak a ReALIS-világocskának néhány elemét, amit Bea Anti hipotéziseire vonatkozó hipotézisei alkotnak (az adott esetben Bea úgy gondolja, hogy Anti is a krimit választotta volna). Jegyezzük meg futólag (elkerülendő az intenzió és az intenció téves azonosítását), hogy az intenzionális profil egy másik világocskája Bea pillanatnyi intencióit, azaz szándékait gyűjtheti össze. 
profilját ezek a tényezők determinálják: önmaga számára kézenfekvő tényt közöl, és biztos benne, hogy partnere számára is kézenfekvő lesz a válasz (egy jól müködő világot feltételezve, kétségtelenül kissé naivan...).

(2) Zoli: Ki a legsikeresebb kutató a karotokon?

Vali: Hát a dékán. Elképesztő impakt faktorral büszkélkedhet, ezért választottuk meg őt dékánnak.

Azért előnyös a hát-funkciókat egy performatív beszédaktusban tanulmányozni, mert így nem merül fel az a tényező, hogy a prozódiát a közlés igazságértéke befolyásolná az adott funkciókban. ${ }^{3}$

\subsubsection{A bizonytalan hát}

$A z$ 1.2. teszthelyzetben a bizonytalanság ${ }^{4}$ kifejezésének a hát-funkcióját szándékoztunk felidézni erre utaló megjegyzéseket elhelyezve mind Bea „magyarázkodó” szövegrészeiben (3), mind eme instrukciós szakaszban:

„Bea nem biztos benne, hogy a legjobb döntést hozta meg, illetve úgy érzi, hogy a pillanatnyi kínálat alapján nincs olyan döntés, amit igazán lelkesen tudna képviselni. Közös tapasztalatnak gondolja a következőket. Korábban néhány krimi kicsit unalmasnak bizonyult, de azért nézhetőnek. Anti vígjátékot szokott választani, de a múlt héten általa választott vígjáték ízléstelenségén már ő is kiakadt. A drámákat pedig Anti ki nem állhatja."

(3) Anti: Na, melyik filmet választottad?

Bea: Hát a krimit

Az azért többé-kevésbé mindkettőnknek be szokott jönni

Az ízléstelen vígjátékokból a múltkor már neked is eleged lett a nyomasztó északi drámákért pedig még én sem rajongok Vagy nagyon unod már a krimiket?

\subsubsection{Az aggodalmas hát}

Az aggodalom kifejezésének funkcióját kívántuk felidézni az 1.3. tesztdialógussal (4) és eme instrukcióval:

„Bea úgy érzi, hogy a krimiket egyre jobban unják, a vígjátékokról pedig a múltkor már Anti is kénytelen volt elismerni, hogy már nem is humorosak, csak gusztustalanul alpáriak. Anti viszont ki nem állhatja a nyomasztó északi drámákat. Bea nagyon jót hallott erről az izlandi filmről egy olyan

\footnotetext{
${ }^{3}$ Felvetjük jövőben tanulmányozandó hipotézisként, hogy valódi dialógusokban az, aki éppen hazudik, pont a diskurzusjelölők és/vagy a töltelékszavak vokális megvalósítása során mulasztja el kontrollálni magát, ezeken keresztül megmutatva a hazugsággal együtt járó feszült állapotot. Ezt azonban nem tartjuk szimulálhatónak olyan tesztekkel, amilyeneket e tanulmányban tárgyalunk, mert az az idegesség, ami a lebukás kockázatának és/vagy a büntudatnak az érzésével jár, aligha ébreszthető fel mesterségesen.

${ }^{4} \mathrm{~A}$ bizonytalanság tehát, ahogy az imént fejtegettük, nem az adott közlés igazságértékére vonatkozik: a választás tényének kimondásával elkerülhetetlenül megvalósult a világban, hogy ez a választás született meg. A bizonytalanság abban áll, hogy érdemes volt-e így dönteni, illetve hogy a döntés következményeit majd szintén viselő partner is így döntött volna-e.
} 
bölcsész haverjától, akinek nagyon tiszteli az ízlését, Anti viszont kifejezetten féltékeny a srácra - talán nem is teljesen alaptalanul. Bea végül úgy dönt, hogy él a választás jogával, de baljós előérzetei vannak. Kínos lesz, ha Anti nagyon firtatja, hogy ki is ajánlotta ezt a filmet..."

(4) Anti: Na, melyik filmet választottad?

Bea: Hát a drámát

Tudom hogy nem nagyon rajongsz ezért a müfajért de mintha ezt az izlandi filmet valahol nagyon dicsérték volna

Asszem valami díjat is nyert

A krimiket már kissé unom a mostanában futó vígjátékok alpáriságából pedig a múltkor már neked is eleged lett úgy emlékszem

\subsubsection{Az incselkedő és a nyomatékosító hát}

$A z$ 1.4. teszt a Schirm (2017) által („Pompom-féle”) incselkedésként emlegetett hát-funkció felidézésére irányult (5), illetve beillesztettünk a dialógusba egy olyan hát-funkciót is, ami szigorúan csak mondatok záróelemeként jelenhet meg, nyomatékosító funkcióval (Id. Bea második beszédfordulóját az (5) dialógusban). Ez utóbbit azzal a szándékkal tettük meg, hogy egy olyan hát-funkció prozódiai jellemzőit is kimérjük, amelyik a mondatban elfoglalt pozíciója alapján egyértelműen elkülönül a másik négytől.

Instrukciónk szerint

„[a] felvázolt helyzetben Bea úgy érzi, hogy a krimiket egyre jobban unják, a nyomasztó északi drámákat pedig Anti ki nem állhatja. Nyomott hangulatba kerül tőle, és egész este azzal szekálná, hogy biztos valami sármos bölcsész srác ajánlgatja neki az ilyen baromságokat. Úgy dönt hát Bea, hogy Anti kedvéért a vígjátékot választja (annyira alpári csak nem lehet, mint a múlt heti vígjáték, mert arról a mélypontról már csak felfelé vihet az út), de azért kicsit incselkedik vele, megenged magának némi játékot, ha már ilyen nagylelkű volt. Az Bea célja, hogy Anti először el se higgye, hogy a múltkori szörnyüség után tényleg a vígjátékot választotta - aztán viszont hogy fog majd örülni (és milyen jó lesz majd a film után az este)!"

(5) Anti: Na, melyik filmet választottad?

Bea: Hát a vígjátékot

Anti: A vígjátékot?!

Bea: $A$ vígjátékot hát

Tudom hogy mennyire élvezed az amcsi vígjátékokat

És úgy szeretem ha vidám vagy este

\subsection{A szembeötlő különbségek}

A fenti párbeszédek diktafonnal kerültek rögzítésre $(44,1 \mathrm{kHz} / 16$ bit), majd a Praat (6.0.40., Boersma 2001) és az SPSS (25.0.0.1) szoftverek segítségével elemzésnek vetettük alá őket. A hát diskurzusjelölő, illetve az azt követő szünet hosszadatainak manuális kinyerése mellett a hát diskurzusjelölő magánhangzójának három pontján mértünk alaphangmagasságot, szintén manuálisan. Az adatközlök egy-egy félperces megnyilatkozásából Gocsál (2012: 6) metodikáját követve meghatároztuk 
átlagos alaphangmagasságukat. A kilenc női adatközlő alaphangmagassága átlagának így 201 (174-225) Hz adódott.

\begin{tabular}{|c|c|c|c|r|r|r|r|r|r|r|r|r|}
\hline$[\mathrm{ms}] \rightarrow$ & $\mathrm{I}_{1}$ & $\mathrm{I}_{1}{ }^{\prime}$ & $\mathrm{I}_{2}$ & $\mathrm{I}_{2}{ }^{\prime}$ & $\mathrm{I}_{3}$ & $\mathrm{I}_{3}{ }^{\prime}$ & $\mathrm{I}_{4}$ & $\mathrm{I}_{4}{ }^{\prime}$ & $\mathrm{I}_{5}$ & Var & $\begin{array}{c}\text { Rec } \\
\text { [a.u. }]\end{array}$ & $\begin{array}{l}\mathrm{P}_{\text {szum }} \\
\text { [a.u.] }\end{array}$ \\
\hline AK1 & 286 & 0 & 432 & 0 & 397 & 0 & 292 & 0 & 420 & 63,41 & 94 & 29 \\
\hline AK2 & 227 & 0 & 551 & 0 & 589 & 15 & 253 & 0 & 386 & 148,5 & 165 & 22 \\
\hline AK3 & 229 & 0 & 383 & 0 & 330 & 0 & 227 & 0 & 280 & 60,06 & 71 & 79 \\
\hline AK4 & 157 & 0 & 1007 & 0 & 1712 & 337 & 253 & 0 & 533 & 572 & 150 & 268 \\
\hline AK5 & 170 & 0 & 580 & 0 & 877 & 193 & 824 & 0 & 459 & 257,1 & 112 & 59 \\
\hline AK6 & 208 & 0 & 377 & 0 & 622 & 102 & 728 & 75 & 559 & 184,8 & 216 & 129 \\
\hline AK7 & 207 & 0 & 599 & 42 & 981 & 491 & 211 & 0 & 505 & 286,6 & 171 & 27 \\
\hline AK8 & 251 & 0 & 515 & 0 & 736 & 123 & 1136 & 0 & 453 & 301,6 & 138 & 24 \\
\hline AK9 & 167 & 0 & 515 & 0 & 652 & 0 & 201 & 0 & 419 & 184,7 & 127 & 71 \\
\hline
\end{tabular}

1. táblázat

A hát hosszúsága $\left(\mathrm{l}_{\mathrm{i}}\right)$, a kitöltetlen/kitöltött követö-szünet hosszúsága $\left(\mathrm{l}_{\mathrm{i}}\right)$ és a frekvencia változása $\left(p_{\text {szum }}\right)$

Az 1. táblázat ezredmásodpercben (ms) mutatja, hogy a kilenc adatközlő milyen hosszan ejtette az öt különböző funkciójú hát-ot $\left(\mathrm{I}_{1}, \mathrm{I}_{2}, \mathrm{I}_{3}, \mathrm{I}_{4}\right.$ és $\mathrm{I}_{5}$ jelöli ezt, az 1. ábra dobozdiagramjai ugyancsak ezt jelenítik meg), és mennyi szünetet tartott utána (erre az $\mathrm{I}_{i}^{\prime}$ értékek utalnak). Az ötödik kategóriához tartozó szünet ( $\left.I_{5}^{\prime}\right)$ nincs értelmezve, mert az érintett hát-előfordulás zárja a mondatot. Ez - a három pontra irányuló alaphangfrekvencia-méréssel $\left(p_{i}\right)$ kiegészített - adathármas $\left(\mathrm{l}_{i}, \mathrm{l}_{\mathrm{i}}{ }^{\prime}, \mathrm{p}_{\mathrm{i}}\right)$ bizonyult elégségesnek a négy vizsgált mondatindító, illetve a mondatzáró hát-funkció biztonságos prozódiai elkülönítéséhez a viszonylag kevés adat mellett.

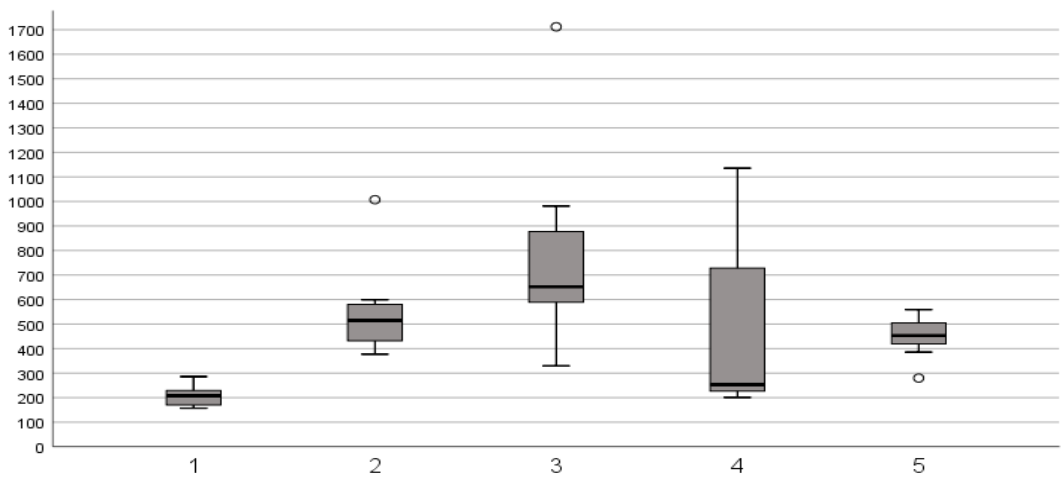

1. ábra

A hát diskurzusjelölő hosszadatai kvartilisjelölő dobozdiagramon ábrázolva $\left(\mathrm{l}_{\mathrm{i}}\right)^{5}$

${ }^{5}$ A ábrák létrehozására az SPSS alapbeállítását használtuk, ami az interkvartilis terjedelem másfélszeresén túl elhelyezkedő adatokat jelöli meg kiugrónak „out values” (kör), illetve szélsőségesen kiugrónak „far out / extreme values” (csillag). 
A monoton adatközlők kiszűrésére első közelítésben megadtuk az adatközlőnként elhangzó, különböző funkciójú hát diskurzusjelölők hosszúságainak a szórását, ezáltal kapva egy minden adatközlőt e tekintetben jellemző számot (Var). Emellett meghatároztunk egy $p_{\text {szum }}$ értéket is, mely a hát-onkénti frekvenciaadat-hármasokból adódó szórással korreláló módon (Pearson-féle korrelációs együttható: 0,992, $p=0,01)$, de ahelyett egy különbségfüggvény formájában jellemzi adott beszélő frekvenciaadatainak szórását. ${ }^{6}$

Ezen a ponton érdemes szót ejteni a Rec kifejezéssel bevezetett sorról is. A recognition 'felismerés' rövidítéséről van szó, és egy olyan vizsgálat végeredményét közöljük itt, amelyben 22 húsz év körüli pécsi egyetemista vett részt (ezúttal fiúk és lányok vegyesen), szintén önkéntesek, szintén nem nyelvészeti érdeklődésǔek, és egyikük sem tartozott a kilenc adatközlő közé. Az ő felismerői szerepük a következőkben állt. Mindenekelőtt aprólékosan ismertettük velük az 1.1.-1.4. tesztsorozat instrukcióit és egyéb körülményeit. Ki is mondtuk, hogy egy határozott, egy bizonytalan, egy aggodalmas és egy incselkedő hát-funkciót kísérelünk meg kimutatni - az előző bekezdésben tárgyalt sajátszórás csökkenő sorrendjében (kezdve tehát az AK4 adatközlővel és zárva AK3-mal), egy-egy adatközlő esetében azonban már véletlen sorrendben (háromszor egymás után) lejátszottuk a négyféle [hát a] szekvenciát. Azt kértük, hogy tippeljék meg, hogy éppen melyik hát-funkció hangzik el, esetleg adva egy (különböző) másodlagos tippet is. Három pontot ért egy alternatíva nélkül írt helyes tipp, két pontot ért egy helyes elsődleges tipp két tipp közül, és egy pontot ért egy helyes másodlagos tipp. E pontok alapján rangsort lehetett felállítani a kilenc adatközlő között. Mint az 1. táblázat Rec oszlopa mutatja, a két - hosszúságszórások alapján - monoton hangsúlyúnak ítélt felolvasó végzett a sereghajtó helyeken (pedig addigra a második kísérlet résztvevői már mindenki mást meghallgattak). Ami AK4-et illeti, az ő túlzott vokális megnyilvánulásai alapján a percepciós kísérlet résztvevői közepes biztonsággal tudták elkülöníteni a hátfunkciókat, míg az AK6 sorszámú adatközlő hát-funkcióit ismerték fel leginkább, akinek a hosszúságszórása az átlagosnál kisebb, illetve AK4 kiugró adatát nem figyelembe véve éppen az átlaggal megegyező volt. Ez arra enged következetni, hogy a különböző funkciójú hát-diskurzusjelölők hosszának gazdagabb variabilitása - egy bizonyos pontig - segítő tényező volt adott funkció beazonosításához, míg a frekvencia $\left(p_{\text {szum }}\right)$ esetében ez kevésbé volt igaz. A frekvenciának és a hossznak a varibilitásáról a felismerhetőség kapcsán a későbbiekben még írunk.

Térjünk is vissza az adatok ismertetéséhez, az 1. táblázat és ábra mellé közölve a kinyert frekvenciaadatokat tartalmazó 2. táblázatot, illetve 2. és 3. ábrákat is. A két ábrán látható, hogy az adatok nulla körül vesznek fel értékeket. Ennek oka, hogy a frekvenciaadatokból kivontuk az adott beszélőnél mért átlagos alaphang-frekvenciát, így a 2. és 3 . ábra az $\mathrm{f}_{0}$-tól való eltérést ábrázolja. A 2. táblázat a már ismertetett számítás segítségével, a három frekvenciaadatból meghatározott $p_{i}\left(p_{1}, p_{2}, p_{3}, p_{4}\right.$, $\mathrm{p}_{5}$ ), illetve $\mathrm{p}_{\text {szum }}$ értékeket tartalmazza, mely az előbbiek összege. Továbbá itt közöljük az egyes beszélőkre meghatározott alapfrekvencia-értékeket is.

${ }^{6} A p_{i}=\sqrt{\left(p_{x}-p_{y}\right)^{2}+\left(p_{x}-p_{z}\right)^{2}+\left(p_{y}-p_{z}\right)^{2}}$ képlet szerint, ahol a $p_{i}$ értékek $\left(p_{1}, p_{2}, p_{3}, p_{4}\right.$, $p_{5}$ ) minden adatközlöre az adott adatközlő 1-5 funkciójú hát-diskurzusjelölőit jellemző értékek, ezek összege pedig a $p_{\text {szum }}$ értékét adja, szintén adatközlőnként. A képletben $p_{x}, p_{y}$ és $p_{z}$ a három ponton mért frekvenciák. 


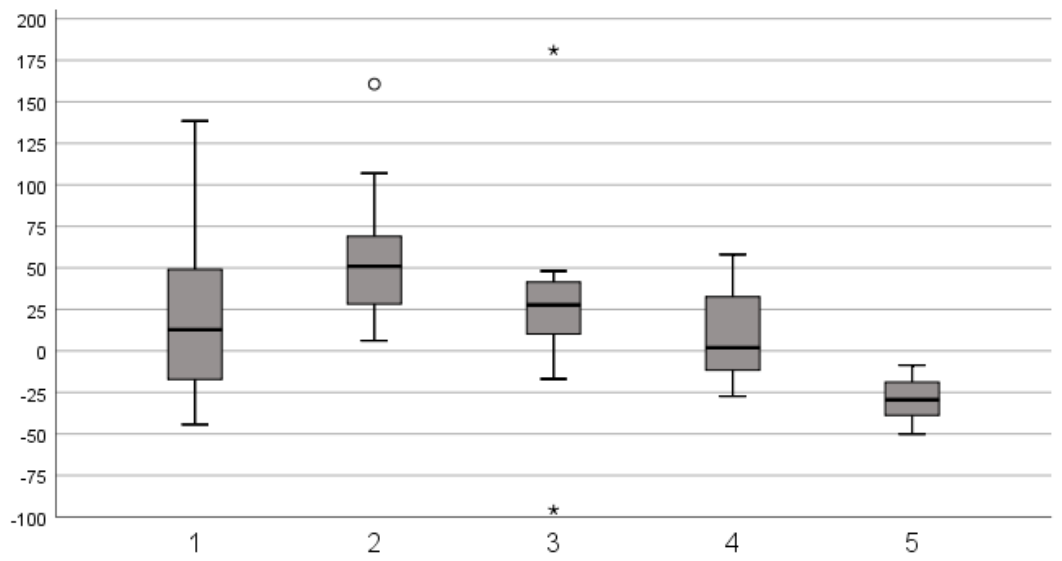

2. ábra

A hát diskurzusjelölő magánhangzójának közepén mért alaphang-frekvenciák dobozdiagramon ábrázolva $\left(\mathrm{p}_{\mathrm{i}}\right)$

\begin{tabular}{|c|r|r|r|r|r|r|r|}
\hline$[$ a.u. $] \rightarrow$ & $p_{1}$ & $p_{2}$ & $p_{3}$ & $p_{4}$ & $p_{5}$ & $p_{\text {szum }}$ & $f_{0}[\mathrm{~Hz}]$ \\
\hline AK1 & 2 & 1 & 24 & 1 & 1 & 29 & 174 \\
\hline AK2 & 3 & 2 & 7 & 9 & 0 & 22 & 223 \\
\hline AK3 & 0 & 31 & 27 & 0 & 21 & 79 & 200 \\
\hline AK4 & 2 & 90 & 176 & 0 & 0 & 268 & 192 \\
\hline AK5 & 17 & 25 & 3 & 13 & 0 & 59 & 194 \\
\hline AK6 & 6 & 60 & 16 & 19 & 29 & 129 & 208 \\
\hline AK7 & 2 & 6 & 19 & 0 & 0 & 27 & 193 \\
\hline AK8 & 1 & 5 & 9 & 7 & 2 & 24 & 197 \\
\hline AK9 & 1 & 38 & 29 & 1 & 1 & 71 & 225 \\
\hline
\end{tabular}

2. táblázat

A különbségfüggvényből származó $p_{i}$ értékek

A határozott hát (2.2.1.) elsöprően elkülönül a másik négytől rövidségével és dallamtalanságával (Id. $l_{1}$ és $p_{1}$ ), ha egy-egy adatközlő $l_{i}$ és $p_{i}$ értékeit összevetjük. Az aggodalmas hát (2.2.3.) azzal tűnik ki, hogy ritkábban olvad össze a következő szóval (megvalósítva az $l_{i}^{\prime}=0$ esetet), mint a többi hát-funkció $\left(I_{3}{ }^{\prime}\right.$ tehát többnyire nem nulla). A nyomatékosító hát (2.2.4.) kötelező mondatzáró pozíciójával egyedíthető, prozódiai jellemzőitől függetlenül. Az alapfrekvenciától negatív irányba történő eltérése arra utal, hogy mélyebben realizálódik a mondatkezdő hát-típusoknál, amire a magyar mondat intonációs adottságait is figyelembe véve térünk még vissza a későbbiekben. Végül az incselkedő hát (2.2.4.) kétféleképpen bizonyult kivitelezhetőnek: az egyik változatban a hát oly rövid ejtésü, mint a határozott hát, a másik változatban viszont - Schirm (2017) ezt említi - nagyon hosszú, ahogy az 1. táblázat $\mathrm{I}_{4}$ oszlopában a három színezett cellában ez a hosszadatokon látható, emellett a 2. táblázat frekvenciaadatait tekintve a három-három $p_{4}$ érték szintén nagy 
eltérést mutatott egymástól ezen adatközlők esetében. Ehelyütt megjegyezzük, hogy az érintett mondat hát utáni szakaszában (ahol az hangzik el, hogy a vígjátékot) a diskurzusjelölő használatakor nem incselkedő adatközlők elnyújtott vagy dallamos ejtéssel bepótolják azt, amit a hát ejtése során elmulasztottak produkálni. Tehát míg célzottan a hát ejtésére összpontosítva két prozódiai stratégiát különíthettünk el, addig az érintett mondat egészét tekintve olyan sejtést fogalmazhatunk meg, miszerint az incselkedést jelző prozódia karakterisztikus elemei számára több mondatszakasz is ideális megjelenési helyként szolgál.

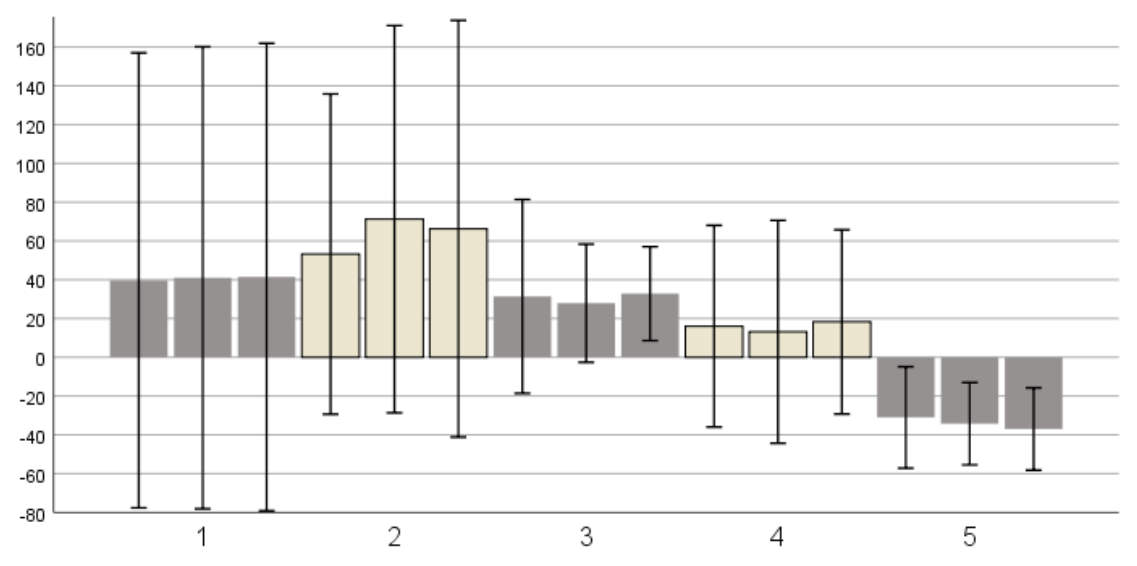

3. ábra

A hát diskurzusjelölő magánhangzójának három pontján mért alaphangfrekvenciaadatok 95\%-os konfidenciaintervallumokkal

\subsection{Statisztikai próbák}

Hogy $a z l_{i}, l_{i}$ és $p_{i}$ értékek ugyanolyan valószínüségi változó megnyilvánulásainak tekintendő sokaságok-e, azt ismételt méréses ANOVA-val teszteltük, majd páronként vizsgáltuk a különböző hát-funkciókat Wilcoxon-féle előjeles rangpróbával, melynek eredményeit a 3. táblázatban közöljük.

\begin{tabular}{|c|c|c|c|c|}
\hline & 12 & 13 & 14 & 15 \\
\hline$I 1$ & 0,008 & 0,008 & 0,011 & 0,008 \\
\hline$I 2$ & & 0,028 & 0,515 & 0,086 \\
\hline$I 3$ & & & 0,139 & 0,011 \\
\hline 14 & & & & 0,859 \\
\hline
\end{tabular}

3. táblázat

Wilcoxon-féle előjeles rangpróba eredménye a különböző párokra

A táblázatban beszíneztük azokat az eseteket, amelyekben - $p=0,05$ szignifikancia szinten - a különbség nem bizonyult jelentősnek a hosszok tekintetében. A 3. táblázat tehát a kilenc adatközlő adatai alapján azt mutatja, hogy az ötféle hát 
kiejtésének hossza páronként általában eltérő, 5\%-os hibahatáron a 10 esetből 4 kivétellel, a nagyon alacsony mintaszám ellenére is. A határozott hát - megerősítve az 1. táblázatból kiolvasható sejtést - szignifikánsan és egyöntetűen rövidebb ejtésü, mint a többi hát-funkció. Viszont a bizonytalan és incselkedő hát nem különül el megbízhatóan a nyomatékosítótól $\left(I_{2} / l_{4}-I_{5}\right)$, illetve az aggodalmas és a bizonytalan hát a kétféle incselkedés „portfóliójától” $\left(I_{2} / l_{3}-I_{4}\right)$. Az előbbi $I_{2} / I_{4}$ elkülönítést $I_{5}$-től a felszíni szintaxis megbízhatóan megteszi: a nyomatékosító hát radikálisan eltér a másik négytől a mondat „túlsó végét” elfoglalva. Egyébként is több vokális jegy együttes vizsgálata alapján kívánjuk elkülöníteni az öt hát-funkciót. ${ }^{7}$

Az utóbbi esetben pedig az 1. táblázat nyilvánvalóvá teszi, hogy az incselkedésre egyszerűen kétféle prozódia áll rendelkezésre, nem egyféle prozódia szétszóródó megnyilvánulásairól van szó. ${ }^{8}$ Mivel egy kivételesen hosszú vagy egy nagyon rövid, inkább a későbbi szekvenciákon incselkedő megvalósítási lehetőség is felmerül, az incselkedő típusról feltételeztük, hogy e kétféle stratégia alkalmazásából következő bimodális eloszlása miatt rendelkezik hasonló hossztulajdonságokkal, mint a bizonytalan és aggodalmas típusok. Hipotézisünket F-próbával támasztjuk alá, ami kimutatja, hogy $\mathrm{I}_{4}$ a szóráshomogenitásban szignifikánsan különbözik $I_{1}(p=0,000), I_{2}(p=0,025)$ és $I_{5}(p=0,001)$ változóktól.

$A$ próba $I_{3}$ esetében nem mutatott ki szignifikáns különbséget $(p=0,932)$, ezért térjünk is rá a második vokális jegyre, a kiejtett mondatindító hát után tartott szünet hosszára! Visszapillantva az 1. táblázatra, látványosan az aggodalmas hát különül el e paraméter alapján az összes többitöl. Minden kategória elkülönítésének érdekében megvizsgáltuk tehát $a z \mathrm{I}_{3}$ és $\mathrm{I}_{4}$ párra a hát diskurzusjelölőt követő néma- és kitöltött szüneteket. Az ANOVA ebben az esetben is a csoportok különbözőségét jelezte $(p=0,001)$, majd - post hoc teszt gyanánt ezúttal is - a Wilcoxon-féle előjeles rangpróbát alkalmazva szignifikánsnak bizonyult, hogy a két eltérő funkcióban a szünetek hossza különbözik $(p=0,028)$. A próbát $a z I_{3}$ és $I_{4}$ párra is elvégezve ugyanilyen $(p=0,028)$ szignifikáns különbséget kapnánk, azonban figyelembe véve azt is, hogy a második pár hozzáadásával az esetek összességére nézve növeltük az elsőfajú hiba lehetőségét, ezúttal is végrehajtottuk a Bonferroni korrekciót. Az új szignifikancia szint $(\mathrm{p} / 2=0,025)$ alapján $5 \%$-os hibahatáron nem vethetjük el a nullhipotézist.

A 4. táblázatban összefoglaljuk az eddigiek alapján, hogy mely vokális vagy szórendi tényező különíti el 5\%-os szinten az öt górcső alá vett hát-funkciót. A H (hamis) $^{9}$, I (igaz) és - (nincsen értelmezve) értékekböl összeállított ötös vektorokban a hamis értékek (a teszthez tartozó nullhipotézist elvethetjük) előnyösek

\footnotetext{
${ }^{7}$ A diskurzusjelölő hosszadatait végül csak az $l_{1}$ elkülönítésére használtuk fel, mivel a határozott hát rövidsége a többi típushoz képest volt egyik fö hipotézise a szemaforhatás elméletnek (Alberti 2016), illetve a mondatindító hát kapcsán Dér és Markó hasonló megállapítást tett (Dér-Markó 2017), melyet a mi vizsgálatunk is alátámaszt. A négy párra $\left(l_{1}-l_{2} / l_{3} / /_{4} / l_{5}\right)$ még az igen konzervatívnak tekinthető Bonferroni korrekció elvégzése után is szignifikáns eredményt kapunk (a mind a négy esetre együttesen állitható 95\%-os szignifikanciát a p/4=0,0125 érték garantálja csak, vö. 1. táblázat első sora).

${ }^{8} \mathrm{Az} \mathrm{I}_{2} / l_{3}$ és $\mathrm{I}_{4}$ közötti eloszláskülönbség kimutatására alkalmazható khí-négyzet $\left(\chi^{2}\right)$ próba legalább 30 adatot kívánna meg.

${ }^{9}$ Mely az li'-értékeket érintő Bonferroni korrekciót figyelembe véve a kis $\mathrm{h}$ formájában nagyobb, 5,6\%-os hibahatárra utal.
} 
tanulmányunk alaptézise szempontjából, miszerint van öt hát-funkció, ami formai jellemzői alapján nagy megbízhatósággal elkülöníthető egymástól, ötféle szemaforállást nyújtva a kommunikáció sínpályáin (megkönnyítve a hallgató számára a neki címzett üzenet feldolgozását). Ugyanakkor két nyelvi jel esetében akár egyetlen eltérő formai jegy is elegendő az elkülönítéshez, mint például a magánhangzóidőtartam a tör és a tör szavak összevetésében.

\begin{tabular}{|c|c|c|c|c|}
\hline & {$[12,12 ', \mathrm{p} 2]$} & {$\left[|3,| 3^{\prime}, \mathrm{p} 3\right]$} & {$\left[14,14^{\prime}, \mathrm{p} 4\right]$} & {$[15,15 ', p 5]$} \\
\hline$\left[11, \mid 11^{\prime}, p 1\right]$ & $-\mathrm{HIII}$ & $-\mathrm{H}-\mathrm{II}$ & $-\mathrm{HIII}$ & $-\mathrm{H}-\mathrm{IH}$ \\
\hline$[\mathrm{l} 2, \mathrm{I} 2, \mathrm{p} 2]$ & & $--\mathrm{hII}$ & $\mathrm{H}--\mathrm{II}$ & $---\mathrm{IH}$ \\
\hline$[13,13,, p 3]$ & & & $--\mathrm{h}$ II & $---\mathrm{HH}$ \\
\hline$\left[14,14^{\prime}, \mathrm{p} 4\right]$ & & & & $---\mathrm{IH}$ \\
\hline
\end{tabular}

4. táblázat

Van-e 5\% esélye, hogy hibázunk annak kijelentésével, miszerint egy adott típusú hát eltér egy másik típusútól a következő tekintetben:

1. A hosszok szóráshomogenitása alapján (F-próba)

2. a hát ejtésének hosszúsága (Wilcoxon-teszt alapján)

3. a követö-szünet hosszúsága (Wilcoxon-teszt alapján)

4. a hát ejtésének eltérése az átlagos alaphang-frekvenciától

(konfidenciaintervallumok alapján)

5. a hát mondatbeli pozíciója (felszíni szintaxis alapján)

\subsection{A statisztikai vizsgálat általános konklúziója és elvarratlan szálai}

Korábban ígéretet tettünk rá, hogy a fejezet végén visszatérünk a frekvenciaadatokkal kapcsolatos megfigyeléseinkre. Az, hogy a mondatéli hát-változatok puszta frekvenciaadatai nem különülnek el szignifikánsan, teljes összhangban van Varga (2016: 52)-nek az előkészítő kontúrral induló kijelentő mondatok dallammenetére vonatkozó általános hipotézisével, amit az alábbi ábra szemléltet:

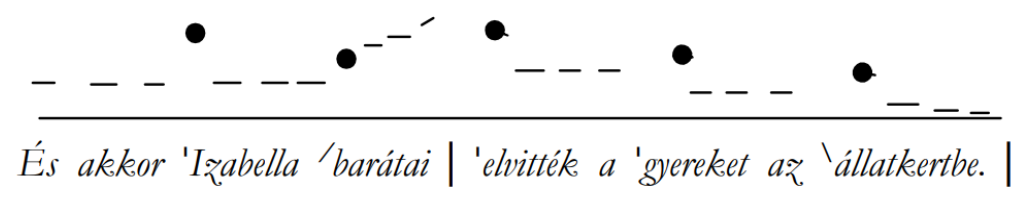

4. ábra

Előkészítő kontúrral induló kijelentő mondatok dallammenete (Varga 2016: 52)

A hát diskurzusjelölő valamennyi mondatéli változata az és akkor szekvencia helyét foglalja el az imént említett előkészítő kontúr zónarészben, ami „lényegében megegyező" $\mathrm{f}_{0}$-t ír elő számukra; ,,játéktér” tehát csak a változatok hosszadataiban rejlik, frekvenciaadataiban nem, vagy csak finomhangolási szinten.

Tekintve, hogy rendelkezünk a már említett percepciós tesztből származó adatokkal is, megvizsgáltuk a korrelációs együtthatókat a felismerés eredménye (rec), a hosszok szórása (hosszvar), és a frekvenciák változása (pszum) között. 
Az eredményeket az 5. táblázatban közöljük. Sajnos a vastagon kiemelt cella kivételével a korrelációk nem szignifikánsak, vélhetően a csekély adatmennyiség miatt. Így csak arra alkalmasak, hogy egy későbbi nagymintás tesztelés számára dolgozzunk ki hipotéziseket, bízva abban, hogy hasonlóan kedvező korrelációs adatok adódnak. Ugyanis az imént említett, Varga-modellel való összhangot erősítik meg: a frekvenciának kis hatása van a jó felismerhetőségre (a korrelációs együttható abszolút értéke kisebb, mint 0,3), a hossznak viszont közepes (0,3-0,5 között van).

A szisztematikus tendenciák feltárása végett szokás a kiugró (outlier) adatokat kizárni a vizsgálatból. Az AK4 adatközlő mind a hosszadatok, mind a frekvenciaadatok tekintetében kiugró, mivel nemcsak hogy a legszélsőségesebb adatokat produkálta, de jó közelítéssel kétszeres értékeket nyújtott, mint a második legszélsőségesebb adat az adott tekintetben (I. az AK4-hez tartozó hosszvar és $p_{\text {szum }}$ értéket az 1. táblázatban). Mint az $n=8$ oszlopa mutatja, növekvő (de a 95\%-os elvárástól még mindig távol eső) szignifikanciaszint mellett a hát-funkciók felismerhetősége már majdnem $(0,469)$ erős korrelációs mértéket $(0,5)$ ölt a hosszra vonatkozó adatokkal. A hát-funkciót tehát a diskurzuselölő hossza alapján azonosítjuk.

\begin{tabular}{|c|c|c|c|c|c|}
\hline \multicolumn{2}{|c|}{} & \multicolumn{2}{c|}{ hosszvar } & \multicolumn{2}{c|}{ pszum } \\
\cline { 3 - 6 } \multicolumn{2}{c|}{} & $\mathrm{n}=9$ & $\mathrm{n}=8$ & $\mathrm{n}=9$ & $\mathrm{n}=8$ \\
\hline Rec & Pearson Correlation & 0,345 & 0,469 & 0,207 & 0,264 \\
\hline & Sig. (2-tailed) & 0,363 & 0,241 & 0,592 & 0,527 \\
\hline hosszvar & Pearson Correlation & \multicolumn{2}{|c}{1} & 0,692 & $-0,199$ \\
\hline & Sig. (2-tailed) & \multicolumn{3}{|c|}{$\mathbf{0 , 0 3 9}$} & 0,637 \\
\hline
\end{tabular}

5. táblázat

Hossz- és frekvenciavariabilitás összefüggései a felismerhetőséggel

Figyelemre méltó a hossz és a dallamosság közötti korreláció mértékének drasztikus megváltozása egyetlen adatközlő kizárásával (0,692-es erős korrelációról 0,199 gyenge negatív korrelációra). A csonkolt minta ezúttal is azt sugallja, hogy a hát-funkciók elkülönítése a hosszra van bízva a nyelvben, dallamosságot belevinni a hosszabban ejtett magánhangzóba az adott funkció szempontjából nem létfontosságú. AK4 adatközlő egyéni - mondhatjuk „dívás” - karaktere mutatkozik meg abban, hogy a hosszabb ejtést szisztematikusan nagyobb fokú dallamosság alkalmazására „használja ki”.

Fontos kutatási feladatnak tartjuk a későbbiekben nagyobb mintán kimutatni, hogy ténylegesen döntően a hosszadatoknak tudható-e be a jó felismerhetőség, összhangban azzal, hogy a produkcióban döntően a hosszadatok különítették el a hát-funkciókat. Az egyes diskurzusjelölők e módon történő vizsgálatával próbáljuk majd meg modellezni a hangsúlyélmény hatásait a percepcióra, többszörös lineáris modellt ráillesztve a nagyobb adatmennyiségre. Továbbá az egyes hát-funkciók mentén külön-külön is vizsgálnánk a hangsúlyélmény összetételét. A pilot-tanulmány - túl azon, hogy plauzibilis hipotézisrendszer kialakításához segített minket arra figyelmeztet, hogy akár egy-egy kiugró karakterű adatközlő is a maga önazonosító jegyeivel drasztikusan módosíthatja a nyelvben konvencionalizáltan müködő distinktív jegyeket. Végső soron az a tét, hogy a performancia hátterében ki tudjuk mutatni az anyanyelvi kompetenciát. 


\section{BDI alapú intenzionális profilokkal különíthetőek el a hát-funkciók?! Azokkal hát!}

\subsection{A ReALIS diskurzusreprezentációs előzményei}

Mint a 2.1. pontban leszögeztük, a Dér-Markó-tanulmány (2017) és előzményei alapján nyitott problémának tekintjük a pragmaszemantikai szempontok alapján felállítandó hát-funkciók kérdését, ahol nagy szükség van olyan új gondolatok termékenyítő hatására, mint a ReALIS kínálta BDI alapú intenzionális profilok bevezetése. Arról van szó, hogy a hát-ot kimondó feladó hipotéziseinek, vágyainak, szándékainak bázisán véljük megvalósíthatónak a funkciók egyértelmü, megbízható, átfedésektől és összemérhetetlen szempontoktól megtisztított meghatározását.

Elsőként megpróbáljuk röviden megvilágítani a ReALIS elmélet (Alberti 2011) lényegi hozadékát a pragmatika és a szemantika tárgyköréhez néhány olyan gondolattal, amelyeket ebben a pillanatban éppen a legaktuálisabbnak ítélünk. ${ }^{10}$

A ReALIS a Kamp-féle formális diskurzusreprezentációs megközelítés, a DRT (pl. Kamp-Genabith-Reyle 2011) pragmaszemantikai továbbfejlesztési kísérlete (hasonlóan például a szintén pragmaszemantikai célkitűzésekkel induló AsherLascarides-féle Szegmentált-DRT elmélethez (Asher-Lascarides 2003), de némileg más utakon próbálkozva). A DRT döntő újítását abban látjuk, hogy a hagyományos logikai rendszerekkel szemben a referencia megragadására nem egy konstans/változó dichotómia áll rendelkezésre, hanem a referensek között egy tetszőleges komplexitású (rekurziós definíciós technikával meghatározható) részben rendezés állít elő olyan hierarchiát, ami a különféle főnévi egységekkel történő természetes nyelvi visszautalásokról hatékonyabban számot tudott adni elődeinél és vetélytársainál, ráadásul vonzó vizuális megjelenítést is kidolgoztak hozzá a jellegzetes dobozstruktúrás ábrázolás révén. Egy egyszerübb és egy bonyolultabb mondat diskurzusreprezentációs struktúrájával szemléltetjük az eljárást (Kamp-GenabithReyle 2011), a lényeg felvillantásának minimális igényével.

Az Every student chose a different topic 'Minden diák más témát választott' mondat (logikai) jelentését reprezentálja az 5. ábra. A bal felső dobozkában megjelenő x referensre nézve a student 'diák' predikátum feltételt, megszorítást ró: a jobb felső doboz világocskájába csak úgy juthatunk be, ha a releváns világszegmensben egy diákra lelünk; ekkor pedig arra nézve kötelezően állítjuk (a $\forall$ szimbólum ezt teszi hozzá a reprezentációhoz), hogy ő talált valamit, ami az ő (különbejáratú) u témája (vagyis minden bemeneti illesztés során potenciálisan új témát rendelünk a „bemeneti” diákhoz. Hogy nemcsak opcionálisan, de egyenesen kötelezően eltérőek az egyes diákokhoz rendelt témák, azt a rombusszal összekötött bal alsó dobozpár fejezi ki: az [x, y] referenspár ezúttal diákpárokat „keres”, és bármely párhoz az $u \neq v$ egyenlőtlenséggel megszorított [u, v] témapárt társítja.

\footnotetext{
${ }^{10}$ Néhány publikáció említésével szeretnénk megmutatni, hogy a ReALIS széles körben alkalmazható pragmaszemantikai problémák megoldására: Alberti (2005), Kleiber (2005), Alberti-Károly (2012), Farkas-Ohnmacht (2012), Alberti-Dóla-Kleiber (2014), Kleiber-Alberti (2014), Alberti-Vadász-Kleiber (2014), Alberti-Nőthig (2015), Kleiber-Alberti-Szabó (2016), Alberti-Kleiber-Schnell-Szabó (2016), Alberti-Kleiber-Kárpáti (2017).
} 


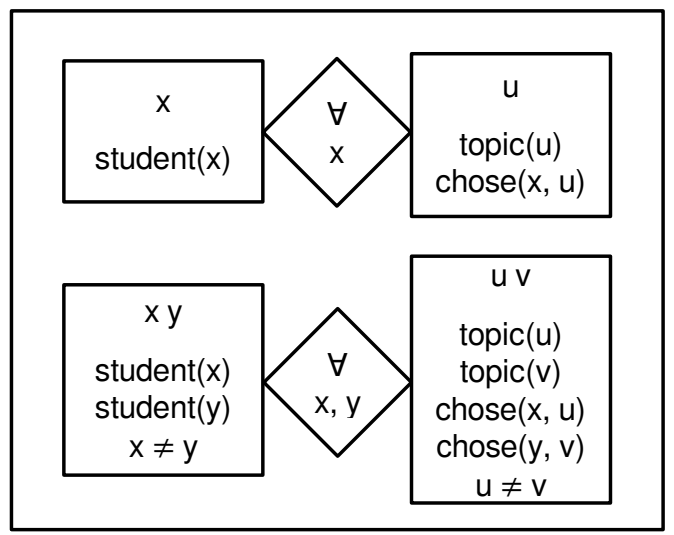

5. ábra

Egy egyszerű mondat diskurzusreprezentációja (Kamp-Genabith-Reyle 2011: 51)

A 6. ábra (bonyolult tér-, idő- és eseményreferens-hálózatának) részleteibe még kevésbé kívánunk belebocsátkozni. A hozzá tartozó minidiskurzus egy olyan mondatpár (Phoebe believes that a man broke into her garden and that he stole her prize zucchini. Ella thinks he didn't take anything.), amely ezt fejezi ki: 'Phoebe úgy hiszi, hogy betört valaki a kertjébe és ellopta a dijnyertes cukkinijét; [míg] Ella úgy gondolja, hogy az illető nem vitt el semmit.'

A befoglaló doboz első két sorában, felül, a valósnak tekintendő szereplők referensei sorakoznak: Phoebe, a kertje és Ella mellett temporális objektumokra (vagyis időpontokra és -intervallumokra) történik itt utalás. Kicsit lejjebb „kiderül”, hogy Phoebe összes díjnyertes cukkinije valójában egyetlen példány. Ami viszont igazán lényeges a tárgyalásunk szempontjából, az az, hogy a BEL (vö. belief 'hiedelem') címkék mögötti dobozvilágocskákban bukkan fel a kertbe behatoló ember, aki a hölgyek hiedelemvilágában létezik (a külvilágbeli létezéséről a diskurzus nem foglal állást), és talán lopkod ( $p=$ Phoebe hiedelemvilágában), talán nem (q=Ella hiedelemvilágában).

A ReALIS-ben az információs dobozoknak - világocskáknak - a részben rendezett viszonyhálózatát eleve tipikusan olyan modális elemek definiálják, mint a BEL hiedelemcímke, valamint a DRT-ben szintén alkalmazott DES és INT címkék, melyek a vágyra és a szándékra utalnak. Eggyel pontosabban fogalmazva, a $\mathfrak{R e A L I S - b e n ~ a ~ r e f e r e n s s z i n t e k e t ~ m e g h a t a ́ r o z o ́ ~ r e ́ s z b e n ~ r e n d e z e ́ s t ~ a ~}$

$$
(\mathrm{M} \times \mathrm{I} \times \mathrm{R} \times \mathrm{T} \times \mathscr{P}\{+,-, 0\})^{*}
$$

formulának megfelelő címkeszekvenciák definiálják (a * a Kleene-csillag, ami tetszőleges véges n számra „legyártja” a hatókörében álló típusból az n-eseket). 


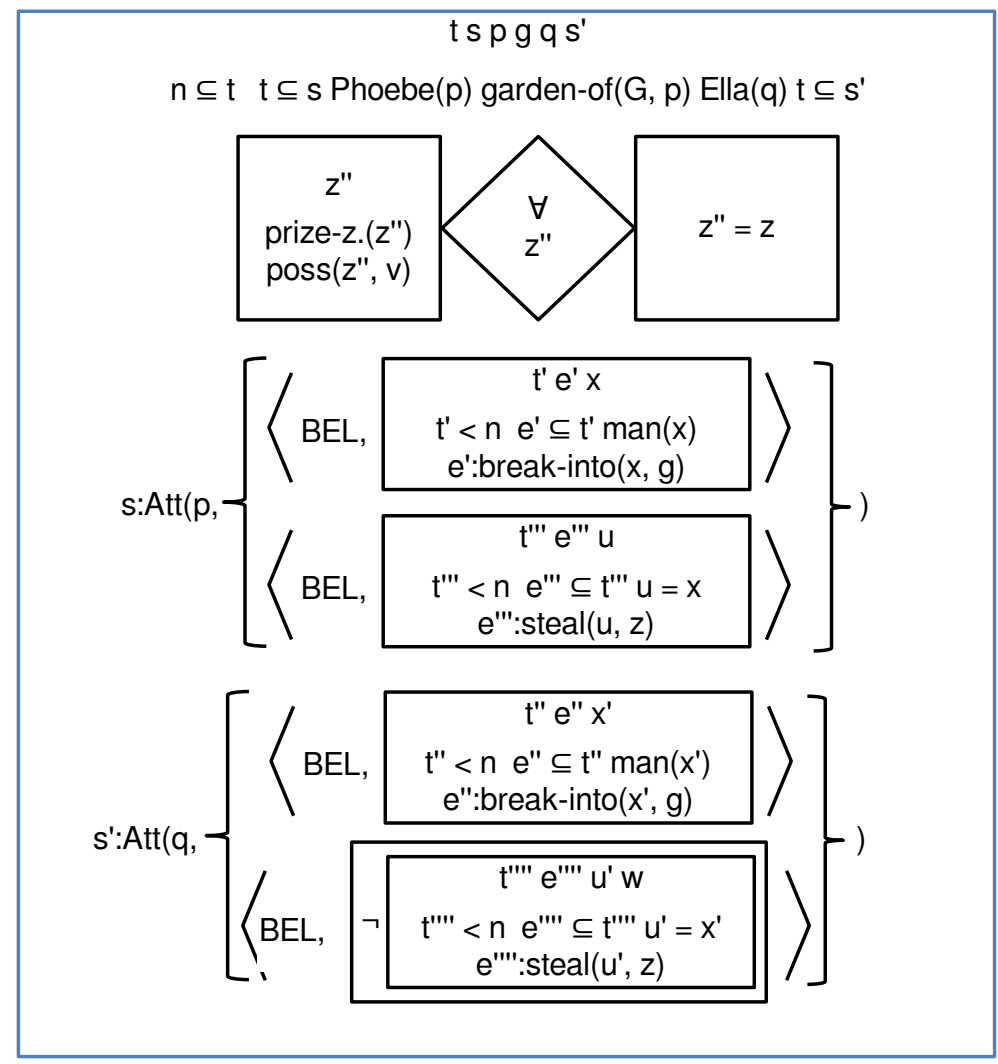

\section{6. ábra}

Egy attitüdigéket tartalmazó mondat diskurzusreprezentációja (Kamp-GenabithReyle 2011: 249)

Mint a 7. ábra mutatja, az információs dobozkák négy sarkába írjuk az ötkomponensű címkét alkotó

- modalitásértéket (M=BEL/DES/INT/...),

- $\quad$ intenzitásértéket (I elemei: pl. MAX: maximális, gr: nagy; I a $[0,1]$ számintervallumként is felfogható, ahol a MAX az 1 végponttal azonosítható),

- $\quad$ címkegazdát (R tipikus értékei: $A R$, a feladó, illetve ae, a címzett),

- $\quad$ illetve egy T halmazból az időpecsétet (az ábrán például a $\tau$ a beszédidő jelen pillanatára utal, míg a $\tau^{+}$egy későbbi pillanatra);

- $\quad$ továbbá minden dobozka valamely oldalára felírunk egy polaritásértéket, a + az IGAZ, a - a HAMIS érték, a 0 pedig értékrésre, vagyis az igazságérték hiányára utal. 


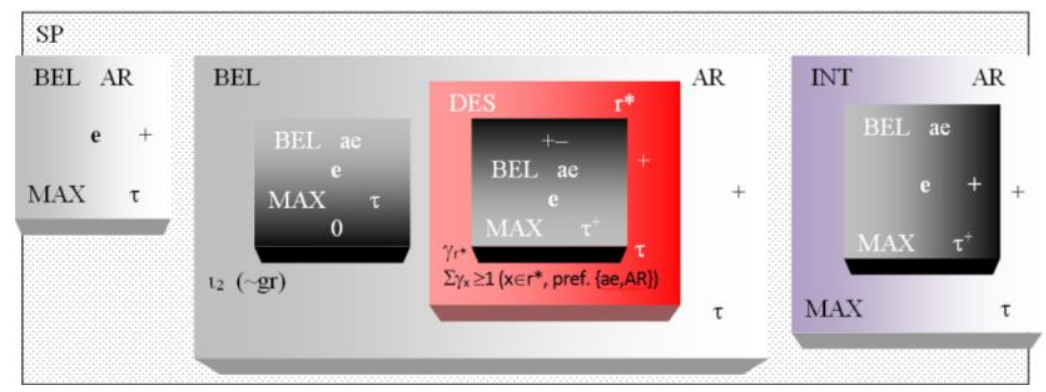

7. ábra

A kijelentő mondattípus feladói profilja a ReALIS reprezentációs rendszerében

A 7. ábra lényegében Grice (1975)-nek a kijelentésre vonatkozó együttmüködési elveit fogalmazza meg a ReALIS BDI alapú eszköztárával. Egy e infon, avagy propozíciós tartalom kijelentő mondatba foglalásával (ez az e van a dobozkák közepére helyezve) a beszélő egy olyan feladói szerepet ölt fel, amellyel ezt mondja a címzetti szerepre például szemkontaktussal kiválasztott hallgatójának (balról jobbra haladva az egy-, két-, három-, majd újra kétemeletes dobozépítmények értelmezésében):

- $\quad\langle B E L, M A X, A R, \tau,+\rangle$ : őszintén állítom e-t, jelenleg biztos tudásom van róla; például arról, hogy e=,Márciusban kölcsönadtam a fiadnak egy laptopot";

- $\quad\langle B E L, g r, A R, \tau,+\rangle \wedge\langle B E L, M A X$, ae, $\tau, 0\rangle$ : azzal az erős hipotézissel bocsátom útra az üzenetet, hogy minőségi információval szolgálok abban az értelemben, hogy te, a címzett nem rendelkezel erről biztos tudással, a konkrét esetben a kölcsönadás tényéröl;

- $\quad\langle\mathrm{BEL}, \mathrm{gr}, \mathrm{AR}, \mathrm{\tau},+\rangle \wedge\left\langle\mathrm{DES}, \mathrm{Y}_{\mathrm{r}^{*}}, \mathrm{r}^{*}, \tau,+\right\rangle \wedge\left\langle\mathrm{BEL}, \mathrm{MAX}, \mathrm{ae}, \mathrm{\tau}^{+}, \pm\right\rangle$: abban az értelemben is minőségi az információ, hogy erősen úgy vélem, hogy erős vágy/érdek füződik ahhoz, hogy te, a címzett a jövőben rendelkezzél az e infon igazságértékével (erre a pontra még visszatérünk);

- $\quad\langle\mathrm{INT}, \mathrm{MAX}, \mathrm{AR}, \tau,+\rangle \wedge\left\langle\mathrm{BEL}, \mathrm{MAX}, \mathrm{ae}, \mathrm{\tau}^{+},+\right\rangle$: maximális együttmüködési szándékom keretében közlésemmel hozzásegítelek, hogy te is ezentúl rendelkezz az e infonnal, vagyis felfrissítem az információállapotodat azzal az állítással, hogy márciusban kölcsönadtam a fiadnak egy laptopot.

Ígéretünkhöz híven visszatérünk a legbonyolultabb harmadik világocskacímkéhez, ami komplexebb, mint a ReALIS korábbi ismertetéseiben. Az ábrába beírt szummázó képlettel kiegészítve az eddig mondottakat és emlékeztetve az olvasót arra, hogy az I intenzitásérték-halmaz egy [0,1] számintervallumként is felfogható, azt kívánjuk kifejezni, hogy - legalábbis a feladói szerep szerint - preferáltan a címzettnek, és/vagy magának a feladónak és másoknak az az érdeke, hogy a címzett értesüljön az e-ről. ${ }^{11} \mathrm{Az}$ alulspecifikált címkeértékek miatt az egy-egy infont

${ }^{11}$ Az adott példában gondolhatja úgy a beszélő, hogy jó, ha tudja a címzett, hogy a fia, akinek korábban két laptopja is volt, laptopokat kéreget kölcsön, mert ennek gyaníthatóan az az oka, 
magába foglaló világocskák összessége e halmaz tagjaként ragadható meg, ahol a cifra $P$ a hatványhalmazképzésre utal: ${ }^{12}$

$$
\mathscr{P}\left([\mathscr{P}(\mathrm{M} \times \mid \times \mathrm{R} \times \mathrm{T} \times\{+,-, 0\})]^{\star}\right)
$$

\subsection{BDI alapú intenzionális profil egy episztemikus ige számára}

\author{
$\{\langle\langle B E L, M A X, A R, \tau,-\rangle\rangle$, \\ $\langle\langle\mathrm{BEL}, \mathrm{gr}, \mathrm{AR}, \mathrm{\tau},+\rangle \wedge$ \\ $\left[\left\langle B E L, s m, r_{E x p}, \tau^{-},-0\right\rangle\right.$, \\ $\left\langle\mathrm{BEL}, \mathrm{MAX}, \mathrm{r}_{\mathrm{Exp}}, \tau,+\right\rangle$, \\ $\left\langle B E L, M A X, r^{*}, \tau,-\right\rangle$, \\ $\left\langle B E L, g r, r^{*}, \tau^{-},-\right\rangle \wedge\left\langle B E L, M A X, r_{\text {Exp }}, \tau^{-},+\right\rangle$, \\ $\left\langle\mathrm{DES}, \mathrm{MAX}, \mathrm{r}^{*}, \tau,+\right\rangle \wedge\left\langle\mathrm{BEL}, \mathrm{MAX}, \mathrm{r}_{\mathrm{Exp}}, \tau,+\right\rangle$, \\ $\left\langle\right.$ INT,MAX, $\left.r^{\star}, \tau^{-},+\right\rangle \wedge\left\langle B E L, M A X, r_{E x p}, \tau,+\right\rangle$, \\ $\left\langle\mathrm{BEL}, \mathrm{MAX}, \mathrm{r}_{\mathrm{Exp}}, \tau,+\right\rangle \wedge\left\langle\mathrm{BEL}, \mathrm{MAX}, \mathrm{r}^{\star}, \tau,+\right\rangle$,
}

A feladó amellett kötelezi el magát, hogy e hamis, vagyis Pál nem nős (1. sor),

és erős hipotézist közöl (2.) a 3-10. sorban megadott alábbi igazságviszonyokról:

Egy $\tau^{-}$korábbi időpillanatban az Experiens, azaz a

bevesz ige alanya némileg sejthette ( $\mathrm{sm}=$ small, azaz valamicske tudás), hogy Pál nem nős, vagy nem volt

Pál státuszáról semmiféle elképzelése (3.), jelenleg viszont úgy tudja, hogy Pál nős (4.).

Ez a változás egy $r^{*}$ személlyel áll összefüggésben, aki (úgy) tudja, hogy Pál nem nős (5.).

Korábban az Experiensről is annyiban hasonlókat feltételezett, hogy nem gondolta, hogy az Pált nősnek tudná (6.)

Az $\mathrm{r}^{\star}$ szereplő vágya az, hogy az Experiens gondolja úgy, hogy Pál nős (7.).

Ez szándékként is realizálódik: lépéseket tesz ezért (8.).

E lépések azon alapulnak, hogy az Experiens előtt olyan benyomást kelt, hogy ő, $r^{\star}$ nősnek gondolja Pált (9.);

miközben az Experiensnek sejtelme sincs arról, hogy $r^{*}$-nak kifejezett szándéka, hogy neki Pál státuszáról határozottnak gondolt tudása legyen (10.).

$\left.\left.\left.\left\langle\mathrm{BEL}, \mathrm{sm}, \mathrm{r}_{\mathrm{Exp}}, \mathrm{\tau}, 0\right\rangle \wedge\left\langle\mathrm{INT}, \mathrm{MAX}, \mathrm{r}^{*}, \tau,+\right\rangle \wedge\left\langle\mathrm{BEL}, \mathrm{MAX}, \mathrm{r}_{\mathrm{Exp}}, \tau, \pm\right\rangle\right]\right\rangle\right\} \in \mathscr{P}\left([\mathscr{P}(\mathrm{M} \times \mathrm{I} \times \mathrm{R} \times \mathrm{T} \times\{+,-, 0\})]^{*}\right)$

hogy a túlzott alkoholfogyasztás miatt kénytelen volt eladni az apjától kapott korábbi két laptopját. A beszélő maga is lehet érdekelt a közlésben, remélve, hogy az apa majd visszaszerzi a kölcsönadott laptopot (amit a fiú talán már szintén eladott, mert a pia bizony drága...). A vágyértékek szummázása azért is jó megoldás, mert az imént ecsetelt két érdek együtt is jelentkezhet. Idekívánkozik egy technikai megjegyzés: az általánosítás kedvéért vállaljuk a kissé furcsa $\langle B E L, L, A R, \tau,+\rangle \wedge\langle D E S, \gamma, A R, \tau,+\rangle \wedge\langle\ldots\rangle$ specifikáció elóállását: „azt gondolom (valamilyen ı bizonyossággal), hogy valamire vágyom ( $\gamma$ bizonyossággal)", azzal a definíciós záradékkal, hogy ez egyenértékủ a $\langle\mathrm{DES}, \gamma, \mathrm{AR}, \tau,+\rangle \wedge\langle\ldots\rangle$ specifikációval, ami ezt fejezi ki: „valamire vágyom ( $\gamma$ bizonyossággal)".

${ }^{12}$ A belső $\mathscr{P}$ utal arra, hogy egy információs dobozka címkéjének bármely komponense lehet alulspecifikált. A tárgyalt esetben több szereplő különféle intenzitású vágyaira utalunk, tehát sem a világocskagazda (AR, azaz feladó, vagy ae, azaz címzett, vagy más) nincs teljesen specifikálva, sem a vágyintenzitás(ok). A 〈BEL, MAX, ae, $\left.\tau^{+}, \pm\right\rangle$címke is megkíván egy megjegyzést: ezúttal a polaritáskomponens alulspecifikált, ami azt fejezi ki, hogy a közlésben érdekelt személy, legalább is feltehetöleg, eredendően nem arra kíváncsi, hogy kölcsön lett adva egy laptop, hanem arra, hogy kölcsön lett-e (!) adva. Tehát eleve nincs elfogultsága az igazságértékre kíváncsi szereplőnek az infon igazságértékére vonatkozóan. Ez a helyzet egy semleges kérdés esetében: „Adtál kölcsön laptopot a fiamnak?” Például az ugye diskurzusjelölő jelezheti, ha nem semleges a kíváncsi fél: „Ugye kölcsönadtál egy laptopot a fiamnak?” 
A ReALIS kézenfekvően kínál BDI alapú intenzionális profilt az episztemikus és attitüdigék számára is. Mint az e pontból kiderül majd, ennek a pragmatika történetét tekintve jelentősége van. Mari bevette, hogy Pál nős - e mondatot a fejünkben tartva tekintsük át Alberti (2011) elemzésének felfrissített változatát a bevesz igére vonatkozóan! E ponton érdemes rámutatni, hogy a sorról sorra megadott és kommentált címkeszekvenciák nem jelentésposztuláló logikai formulák, hanem lehetségesvilágszerü konstruktumok (Dowty-Wall-Peters 1981) azonosítói: megadjuk azokat a lehetséges világokat, amelyekben a bevesz ige tárgyi argumentumát képező e propozíció - legalább is a feladói profilban - meghatározott polaritásértéket kell, hogy felvegyen. A 9. sorban megadott világocska például (egy lehetségesvilág-család tagjainak véges metszete) a feladó azon hipotéziseinek gyüjteménye, amelyek arra vonatkoznak, hogy az Experiens mit feltételez egy intrikusként megjelenő személy tudásáról.

\subsection{A $\Re$ eALIS helye a pragmatika világában}

Bízunk benne, hogy az olvasót az előző két pont meggyőzte arról, hogy a ReALIS a logikoszemantikai ihletésü információ-részbenrendezést legalább egyes területeken át tudja értelmezni úgy, hogy pragmatikai jelenségek megragadása váljon lehetővé. E pontban szeretnénk általánosságban elhelyezni a ReALIS-megközelítést a pragmatika világában, mégpedig egy Austin, Searle és Mey alapgondolatait összevető Oishi-cikk gondolatrendszerében kijelölve azt (Oishi 2016). ${ }^{13}$

Oishi (2016: 337, 340) számára fontos kiindulópont, hogy Austin egy helyen (Austin 1975 [1962]: 150) 1000-9999 illokúciós aktust említ a „szokásos” öt helyett - verdiktív (ítélkező), exercitív (végrehajtó), komisszív (elkötelező), behabitív vagy konduktív (viselkedő) és expozitív (bemutató); az óriási számbeli különbséget annak tulajdonítja, hogy Austin a beszédaktusokat egyáltalán nem merev szabályok alapján pontosan definiálható kategóriáknak tartja, hanem a számuk azon múlik, hogy mennyire finoman részletezett különbségek alapján határoztatnak meg. Mivel pedig - folytatja - nincsen az angolban 1000-9999 számú „illokúciósaktus-ige”, ezért nem feltételezhető Austinról, hogy egy-az-egyhez kapcsolatot képzelt volna el az illokúciós aktusok és bizonyos igék között, még ha vannak is népes igeosztályok, amelyek tagjai kézenfekvő forrását jelentik beszédaktustípusoknak (Id. 3.2.). ${ }^{14}$ Maga Austin

${ }^{13}$ Oishi (2016) Austin (1975 [1962]) How to do things with words című klasszikusát veti össze Mey (2001) népszerü pragméma-elképzelésével, állítva, hogy Mey - a látszólag nagy különbségek ellenére - lényegében Austin nyomdokain halad, szemben a pragmatika irányvonalára nagy hatást gyakorló Searle-lel (Searle 1969; 1979; 1983), akivel kapcsolatban félreértésnek nyilvánítja, hogy Austin beszédaktus-elméletének hű továbbvivője és kiterjesztője lenne, sőt azt állítja, hogy Searle egyes értelmezései nyomán sok félreértés keletkezett Austin eredeti beszédaktus-felfogásával kapcsolatban. Mindennek részleteibe csak annyiban fogunk belemenni, amennyiben az a ReALIS pragmatikai helyzetének kijelölése szempontjából releváns.

${ }_{14}$ Oishi (2016: 340): „The concepts of the locutionary, illocutionary and perlocutionary acts are invented for elucidating different sources and effects of language use, not for confining speech acts in real life by classifying them into rigid classes. This essence of Austin's speech act theory is hardly recognized, which is largely due to the identification of Austin's (1975) theory with Searle's $(1969,1979,1983)$ : it is taken for granted that Austin's seminal idea of speech acts is developed and completed by Searle, in spite of the fact that their ideas are different at crucial points." 
(1975 [1962]: 152) is rámutat (Oishi 2016: 344), hogy például a viselkedő beszédaktusok kategóriája mennyire problematikus: megfoghatatlanul vegyes ez a társaság, a bemutató beszédaktusok pedig a rendszert megkérdőjelezően óriási és aránytalanul kiemelkedő fontosságú kategóriába vannak bekényszerítve, felvetve a lehetőségét akár annak is, hogy minden beszédaktusosztályban potenciálisan mind az öt aspektus (az ítélkezéstől a bemutatásig) szerepet játsszon.

Mindezek után Oishi (2016: 338) a klasszikus austini boldogulási/szerencsésségi feltételeket (arra vonatkozóan, hogy hogyan kell egy illokúciós aktust megfelelőképpen végrehajtani és hatását elérni) lényegében imígyen „korszerüsíti”, alapvetően terminológiai finomításnak ítélve javaslatait: ${ }^{15}$

Egy adott helyzetben egy megnyilvánulást létrehozó adott beszélö elkülönül az illokúciós aktus előadójától, akit az aktus feladójának nevezhetünk. A hallgató, akihez a beszélő a szavait intézi, ugyancsak elkülönül az illokúciós aktus címzettjétôl. A megnyilvánulás körülményei pedig elkülönülnek a beszédaktus kontextusától. Annak elsődleges alapfeltétele, hogy az illokúciós aktus megtegye konvencionális hatását, az, hogy a beszélő, a hallgató és a beszédszituáció körülményei rendre azonosíthatóak legyenek a feladóval, a címzettel és az aktus kontextusával. Továbbá a beszélőnek pontosan kell követnie a beszédaktushoz tartozó procedúrát, a hallgatónak pedig jóvá kell hagynia az aktust, hogy így tegye teljessé a procedúrát. Ami pedig a ReALIS nézőpontjából legfontosabb Oishi-kritérium: a beszélőnek az aktus feladója számára [a nyelvi konvenció révén] meghatározott gondolattal vagy érzéssel vagy szándékkal kell rendelkeznie, és ő [és/]vagy a hallgató viselkedjen pontosan aszerint, ahogyan az [konvencionálisan] meg van határozva a feladó és/vagy a címzett számára.

A fentiekben meghatározott elválasztását a nyelvileg definiált, azaz konvencionálisan előirt karakterü [feladó, címzett, kontextus] szerephármasnak a [beszélő, hallgató, beszédhelyzet] aktuális hármastól Oishi meglátása szerint Searle - Oishi szerint helytelenül - nem tartotta perdöntő fontosságúnak. A ReALIS viszont ezt a differenciálást és a ráalapítható megfeleltetést a formális elméletekre jellemző

\footnotetext{
${ }^{15}$ Megadjuk az eredeti Oishi-szöveget, hogy a fordítás során óhatatlanul beszüremkedő továbbértelmezést detektálhassa az olvasó, amennyiben szükségesnek tartja: „To clarify how an illocutionary act is performed felicitously and brings about an effect, let us specify the terminology. A particular speaker in a given case who makes an utterance (in (A.2) [see Austin 1975: 14-15]) is distinguished from the performer who performs a particular illocutionary act (specified (A.1)), whom we call the addresser of the act. The hearer to whom the speaker speaks (in (A.2)) is also distinguished from the person to whom the illocutionary act is performed (specified by (A.1)), whom we call the addressee of the act. The circumstances of the situation in which an utterance is made (in (A.2)) are distinguished from the context of the act (specified by (A.1)). The illocutionary act brings about its conventional effect when (i) the speaker, the hearer, and the circumstances of the speech situation are assumed to be the addresser, the addressee, and the context of the act, respectively (felicity conditions (A.1) and (A.2)), (ii) the speaker follows the procedure correctly (felicity condition (B.1)), (iii) the hearer ratifies the act (or the speaker makes a specific sequel) for the procedure to be completed (felicity condition (B.2)), (iv) the speaker has the thought or feeling, or intention of the addresser of the act (felicity condition ( .1$)$ ), and (v) the speaker or the hearer conducts her/himself subsequently as is specified for the addresser/addressee of the act (felicity condition_.2)"
} 
legmagasabb szintű pontossággal és egzaktsággal meg tudja ragadni, mégpedig Montague-féle - igazságfeltételesen értékelhető - mintaillesztés gyanánt. A ReALIS elsődlegesen e szemlélet keretei között tud belépni a pragmatika világába, miközben természetesen Searle és követői széles körü eredményeit is fokozatosan bevonjuk formális megközelítésünk világába.

A pragmatikai dimenzió tehát úgy jelenik meg a Montague-Kamp-féle logikoszemantikai diskurzusmegközelítés kiterjesztőjeként, mint a klasszikus mintaillesztő igazságértékelés mindenféle pragmatikailag figyelembe veendő körülményre való általánosítása, alkalmazása. A Le tetszett verni azt a drága pezsgót mondat értékelésének például egyenrangú eleme az, hogy (i) megvizsgáljuk a világban, hogy a hallgató tényleg leverte-e (tényleg ő verte-e le) a drága italt, (ii) valóban így gondolja-e a beszélő (vagy pontosan tudja, hogy ő volt a tettes, és így neki kéne kifizetnie a kárt), (iii) a beszélő korbeli és egyéb különbségeik alapján jogosan használja-e a tetszikező formát, illetve (iv) a mutató névmás és az adott beszélői gesztusok elégségesek-e a pezsgő hallgatói azonosításához.

\subsection{Az öt hát-funkció BDI alapú intenzionális profiljának poliszém rendszere}

A 3.1.-3.2. pontokban felvázolt BDI alapú formális reprezentációs rendszer a 8. ábrán bemutatott intenzionális profilokat kínálja az öt hát-funkció pragmaszemantikai kontribúciójának megragadására, legalábbis első közelítésben. ${ }^{16} \mathrm{Az}$ adott kontribúció a 3.1. pontbeli 7. ábrán bemutatott kijelentő mondati intenzionális profilhoz járul hozzá, ehhez hozzátéve, hogy a kísérletekben szereplő választom performatív igealak lerögzíti, hogy a hát-tal módosított mondatok elkerülhetetlenül igaz állítások (a mondat kimondásával a világban létrejött az azt bizonyosan igazzá tevő változás). A megadott intenzionális profilok a kísérletben „Bea gondolataiként” megadott állítások „BDI-nyelvre való fordításai”. A különféleképpen ejtett hát-verziókra vonatkozó saját anyanyelvi intuíciónkat tehát ellenőriztettük az adatközlőkkel, akik lényegében olyan prozódiát adtak, amilyent mi is elképzeltünk, majd még egyszer ellenőriztettük a 2. teszt alanyaival, akik jó hatékonysággal felismerték e funkciókat a hát_a szekvenciák alapján. Az alábbiakban még egy ellenőrzési eljárást fogunk bemutatni (legalábbis az első két hát-funkció esetében), ami visszakanyarodik saját anyanyelvi intuíciónk introspektív alkalmazásához (remélve, hogy az olvasó

\footnotetext{
${ }^{16}$ Azért tesszük hozzá, hogy „első közelítésben”, mert a jelenlegi kutatási fázisban - értve ez alatt a legutóbbi tíz év $\Re$ ReALIS-projektjeit - a nyelvi formákhoz „egy lehetséges”, a megfigyelt pragmaszemantikai karakterük egyértelmű vonásairól jól számot adó profilt tudunk javasolni, ami nem feltétlenül az „egyetlen lehetséges” végső leírás. Ez utóbbi cél eléréséhez oly kiterjedt vizsgálatokra van szükség, amelyek az egy-egy nyelvi formához tartozó teljes poliszém hálózatok feltárását célozzák meg, majd az egymást kiegészítő poliszém hálózatok rendszerszerű viselkedésének feltárását; e távoli célok felé jelenleg az első lépéseket tesszük meg. Nyilván például az első lépés: egy nyelvi formához megadni egy „pontszerü” prototipikus intenzionális profilt, ahol minden címkekomponens egyetlen konkrét értéket mutat. Erős hipotézisünk, hogy - összhangban a mag/preiféria modell elképzelésével (Bell 1998) - valójában konkrét értékek helyett sok helyen értéktartományokat kell keresni, feltehetőleg nem is éles, hanem csökkenő valószínűséggel jellemezhető elmosódó határokkal. Ami még olyan közönséges szavak esetében sem könnyű, mint mondjuk a szék (meddig szék egy bútordarab, és honnan fotel vagy hokedli?).
} 
hasonló ítéletekre jutna): be-behelyezkedünk egy olyan címzettnek a helyébe, akiről a javasolt feladói profilban téves feltevés van. A módszer lényege: megerősíti a javasolt profilt az, ha a címzettből korrekciót vált ki az adott közlés, hiszen ez az előfeltevés téves voltára mutat rá.

Ezek, a profilokkal párhuzamosan ismertetett nyelvi evidenciák és a második szakaszban bemutatott kísérleti eredmények támasztják alá a szerzők anyanyelvi intuícióját, kiegészítve azzal, hogy az ismertetésre kerülő BDI-alapú intenzionális profilok értékeit eloszlások mentén működőnek tekintjük. Ez azt jelenti, hogy az általunk posztulált lehetségesvilágok az adott szituációban a feladói szerepre legideálisabb beszélő elméjének lehetséges világait jelenítik meg.

\begin{tabular}{|c|c|c|c|c|}
\hline 1: Hát_a... & 2: Hááát_a... & \multirow{4}{*}{ 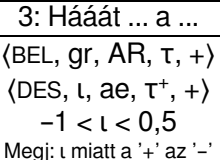 } & \multirow{4}{*}{ 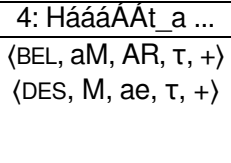 } & 5: ... hát! \\
\hline \multirow{2}{*}{\multicolumn{2}{|c|}{$\begin{array}{c}\langle\text { BEL, gr, AR, } \mathrm{T},+\rangle \\
\left\langle\mathrm{BEL}, \mathrm{l}, \mathrm{ae}, \mathrm{T}^{+},+\right\rangle\end{array}$}} & & & \\
\hline & & & & \\
\hline$>0,5$ & $-0,5<l<0,5$ & & & \\
\hline \multirow{2}{*}{\multicolumn{2}{|c|}{$\begin{array}{c}\langle\text { BEL, gr, AR, } \mathrm{T},+\rangle\left\langle\mathrm{BEL}, \mathrm{gr}, \mathrm{ae}, \mathrm{\tau}^{+},\right. \\
\quad+\rangle\langle\mathrm{BEL}, \mathrm{L}, \mathrm{AR}, \mathrm{\tau},+\rangle\end{array}$}} & $\langle\mathrm{BEL}, \mathrm{gr}, \mathrm{AR}, \mathrm{\tau},+\rangle$ & \multirow{3}{*}{$\begin{array}{l}\langle\mathrm{BEL}, \mathrm{gr}, \mathrm{AR}, \mathrm{\tau},+\rangle \\
\left\langle\mathrm{BEL}, \mathrm{gr}, \mathrm{ae}, \mathrm{T}^{+}, 0^{-}\right\rangle\end{array}$} & \multirow{3}{*}{$\begin{array}{c}\langle B E L, g r, A R, \tau,+\rangle \\
\langle B E L, \iota ", a e, \tau,+\rangle \\
-1 \leq \iota " \leq 1 \text { de } \\
\iota " \neq 0 \\
\text { elófeltétel }\end{array}$} \\
\hline & & $\begin{array}{c}\left\langle\text { BEL, gr, ae, } \tau^{+},+\right\rangle \\
\left\langle\text {DES, }, \gamma_{r^{*}}, r^{*}, \tau,+\right\rangle \\
\sum \gamma_{x} \geq 1\left(x \in r^{*} ; \text { pref. ARE } r^{*}\right)\end{array}$ & & \\
\hline \multicolumn{2}{|c|}{$\begin{array}{l}\text { ugyanazon ı érték mellett } \\
\text { (elmeszinkronizálás) }\end{array}$} & $\begin{array}{c}\text { l' erős } \\
\text { intenzitásérték }\end{array}$ & & \\
\hline & & $\begin{array}{l}\langle I N T, M, s p, \tau,+\rangle \\
\left\langle B E L, M, l i, \tau^{+},+\right\rangle \\
\langle B E L, g r, s p, \tau,+\rangle \\
\left\langle D E S, \iota, a e, \tau^{+},+\right\rangle\end{array}$ & $\begin{array}{l}\langle\text { INT, M, AR, T, +ो } \\
\left\langle\mathrm{BEL}, \mathrm{M}, \mathrm{ae}, \mathrm{T}^{++},+\right\rangle\end{array}$ & $\begin{array}{l}\langle\text { INT, M, AR, T, +ो } \\
\left\langle B E L, M, \text { ae }, \tau^{+},+\right\rangle\end{array}$ \\
\hline
\end{tabular}

8. ábra

Az öt hát-funkció intenzionális profilja

A határozott hát feladója azt az erős hipotézisét ${ }^{17}(\langle\mathrm{BEL}, \mathrm{gr}, \mathrm{AR}, \mathrm{\tau},+\rangle \wedge \ldots)$ hozza a címzett tudomására, hogy nem fog meglepőt mondani, vagyis a közlés előtti címzetti információállapotból (egy $\tau^{+}$„rákövetkező pillanatra”) elég jó bizonyossággal (a t-ra vonatkozó egyenlőtlenség ezt próbálja megragadni) a majdan érkező állítást vezetné le a címzett maga is; és ez olyan közös tudáselemeken alapul, hogy a címzett is - a feladó meggyőződése szerint ( $\langle\mathrm{BEL}, \mathrm{gr}, \mathrm{AR}, \tau,+\rangle \wedge\left\langle\mathrm{BEL}, \mathrm{gr}, \mathrm{ae}, \mathrm{\tau}^{+},+\right\rangle$ ...) - ezt a kalkulációt várja a feladótól (tendenciájában azonos l-érték mellett). A hát prozódiája tehát a két elme szinkronizált működésének lehetőségét jelzi, mintegy megnyugtatva a hallgatót, hogy majd nem kell az agyát megdolgoztatnia a leendő közlés feldolgozása során.

„Hát a krimit!” - ezt a határozott közlést hallja a hallgató. Ugye a következő egy lehetséges reakció: „A krimit?!” Ez a potenciális visszautasító reakció az első világocskacímkét erősíti meg, amennyiben a hallgató ezt is hozzáteszi: „... Az elmúlt hónapok sok unalmas krimije után erre a döntésre számítottam legkevésbé!" Hiszen ezzel a hallgató jelzi: tévesen kapta egy olyan címzett szerepét, aki a krimire szavazott volna. Amennyiben pedig így folytatja a hallgató, „... Azt hittem, te

${ }^{17} \mathrm{Az}$ intenzitásskála elemeinek feloldása a következő: $\mathrm{M}$ (maximal), aM (almost maximal), gr (great), sm (small), azaz az intenzitás ebben a sorrendben csökken. 
kifejezetten untad az elmúlt hónapok krimijeit”, akkor a címzetti szerep második világocskacímkéjét utasítja vissza: nem gondolta volna, hogy a beszélő ily pozitívan áll a krimikhez.

Mint a második oszlop mutatja, a bizonytalan hát-ot is elmeszinkronizációként elemezzük, csak ezúttal a bizonytalanság a közösnek feltételezett faktor: a konkrét esetben a krimi választására kis esély volt, sőt inkább a nem választására volt némi esély (amivel összefér, hogy az alternatívák között sincs nagy(obb) esélyű). Az ezt megragadó ı-küszöbértékek azt az intuíciónkat tükrözik, hogy a beszélő nem ezt az intonációt használná, ha akár ő, akár (feltételezhetően) a partnere nagyon egyértelmüen a krimi ellen lenne; a pontos küszöbértékek meghatározása persze jelenleg még ki nem dolgozott technikákat igényelne. Még egy technikai részlet: a negatív ı intenzitásérték úgy értelmezendő, mint pozitív ellentettje negatív polaritásérték mellett.

Ezúttal is próbára tehetjük a javasolt elemzést, például ilyen hallgatói reakció megítélésével: „Mit rágódsz?! Számomra nem kérdés, hogy csak a krimi jön szóba!” Ha az olvasó intuíciója is az, hogy ez egy természetes reakció, akkor igazoltnak tekinthetjük azt, hogy a beszélő az adott kérdésben bizonytalan státuszt elfoglaló címzett szerepét osztotta rá a hallgatóra - a reakció alapján tévesen. Ugye lehet a következő is a reakció? „Mit rágódsz?! Számodra kérdés, hogy csak a krimi jön szóba?!" Ezzel a profil másik elemét erősítjük meg: a hallgató számára érthetetlen, hogy a beszélő miért tartja kétséges döntésnek a krimit.

A harmadik (középső) oszlop az aggodalmas hát számára javasolt intenzionális profilt mutatja be. Hogy a $[-1,+1]$ intervallumot felosszuk a hát-funkciók között, a címzettre vonatkozó feladói hipotézisben pozitív polaritásértéket írtunk, de a negatív ı intenzitásérték miatt ezzel ténylegesen negatív polaritást írunk le. És ezúttal nem BEL típusba sorolható feltételezett címzetti elvárásról van szó, hanem a DES típusba sorolható érzelemről. A konkrét esetben a címzettről feltételezhető, hogy nem örül a választásnak. Visszautasító reakció erre ilyesmi lehet: „Ne parázz! A kedvedért szívesen megnézem ezt a drámát."

A feltételezhető címzetti ellenérzés még nem követeli meg a hát használatát, a konkrét esetben is lehetne „szenvtelenül” csak ennyit mondani: „A drámát!”. Anyanyelvi intuíciónk azt súgja, hogy az aggodalmas hát beiktatása némi indoklásszerü szabadkozást tesz hozzá a döntés közléséhez (NB: az előző bekezdésben említett reakcióban e szabadkozás elfogadása is ott van). A kijelentő mondat profiljából „kölcsönvéve” az érdekösszegző formulát, és feltételezve, hogy a poliszém jelentéshálózatban erre az esetre is öröklődik a feltételezett címzetti hipotézis megléte $\left(\langle\mathrm{BEL}, \mathrm{gr}, \mathrm{AR}, \tau,+\rangle \wedge\left\langle\mathrm{BEL}, \mathrm{gr}, \mathrm{ae}, \mathrm{\tau}^{+},+\right\rangle \ldots\right)$, mégpedig az első világocskacímkében szereplő modalitásra vonatkozóan (ami ezúttal DES) e hipotézis most az lehet, hogy a címzett is minden bizonnyal sejti, hogy az ellenérzését kiváltó döntés mellett komoly támogató érdekek vannak, a legegyszerübb esetben magának a feladónak a részéről („,ugye tudod, hogy én ezt egy igen pozitív l' mértékben szeretném?”). Felvetjük, hogy az aggodalmas hát-ra jellemző (esetenként kitöltött) követő-szünet lehet az a formai komponens, ami a feltételezett címzetti (ellen)érdek és a feladói érdek ellentétes voltára hívja fel a figyelmet, azaz a poliszém jelentéshálózatba beviszi az ellentétesség faktorát.

A harmadik oszlop legalsó sorában ezt fejezi ki a világocskacímke: „a beszélő (sp(eaker)) határozott szándéka, hogy hallgatója (li(stener)) tudatában legyen 
annak, hogy a beszélő tisztában van azzal, hogy hallgatója egy igen negatív ı intenzitással vágyik arra, amit hall (vagyis nem örül neki)”. „Értékeld, hogy legalább nem játszom a naivat!" - ezt olvashatja ki a hallgató az aggodalmas hát-ból. Az, hogy ezúttal nem feladóról és címzettről beszélünk, hanem beszélőről és hallgatóról, azért van, mert nem konvencionálisan „indikált” pragmaszemantikai kontribúciónak gondoljuk ezt az elemet (ellentétben az eddig tárgyaltakkal), hanem implikáltnak. Mégpedig azon az alapon, hogy mivel a beszélőközösség számára (implicit módon, de) ismertnek, adottnak, a diskurzusjelölő nyelvileg kódolt hozadékának tekintjük az intenzionális profilokat, ezért a hallgatónak mindig rendelkezésére áll egy olyan implikáció akkommodálása, miszerint az üzenethez társuló intenzionális profil valamely elemét a beszélő szándékosan hozza a hallgató tudomására. Egy-egy üzenet pragmaszemantikai kontribúcióját tehát általánosságban úgy képzeljük, hogy van egy kötelezően indikált magva (ennek meghatározása az elsődleges kutatói cél), amit körbevesz egy általános lehetőségek mentén generálható (elvileg korlátlan kiterjedésű) implikációs „,burok” (vö. mag/periféria modell: Bell 1998). Ez a megközelítés jól magyarázza, hogy miért oly nehéz konszenzusra jutni abban, hogy egy nyelvi elem pontosan mit ad hozzá a pragmaszemantikai tartalomhoz (hogy miért oly nehéz elkülöníteni az indikáltat az implikálttól, vö. Oishi (2014: 247)).

Az incselkedés pragmaszemantikai kontribúciója a poliszém hálózatban eddig feltárt szinkronizáló, ellentétjelző és érzelmi faktorok sajátos kompozíciójaként írható le, két jövőbeli idősík felvételével, amit a prozódiai megjelenítésben valahogyan mindenütt megjelenő elnyújtott/túldallamosított mondatszakasz által kiváltott új faktorként foghatunk fel. A feladó tisztában van az illető pozitív érzelmével egy bizonyos tartalomra vonatkozóan (érzelmi faktor!); ugyanakkor azt is gondolja, hogy egy „rákövetkező pillanatra” a címzett ellentétes tartalomra jutna információállapota alapján (ellentét!); végül viszont megtudja, hogy a pozitív tartalom áll fenn (szinkronizálás!). Felülről indulva ezt fejezi ki a három megadott világocskacímke.

A mondatzáró nyomatékosító hát - amennyiben a poliszém hálózatban az incselkedést vesszük alapul - annak profiljából a középső és az alsó elemet veszi át. $\mathrm{Az}$ utóbbit egy az egyben: a feladó leghatározottabb szándéka, hogy a címzett tudatosítsa az átadott tartalmat. A középső, ellentétet kifejező profilelem pedig mint e hát-funkció használatának előfeltétele jelenik meg: akkor használható, ha a címzett észlelhetően nincs (még) meggyőződve az adott tartalomról, esetleg egyenesen annak ellentétét látszik hinni.

\subsection{Poliszémia?}

A 3.4. pontban a diskurzusjelölők multifunkcionalitásáról felállított poliszémiaelgondolás jegyében (Fischer 2006: 13-14) állítottuk fel a hipotézisünket a hát-funkciók pragmaszemantikai kontribúciójáról, többek között azért, mert - ha másért nem, hát a nyelvet elsajátító gyermek „érdekében” - hiszünk abban, hogy a szövevényes jelenségek mögött is néhány egyszerü elv vezérelte struktúra rejlik (pl. Chomsky 2013). A kijelentő mondat 3.1.-ben bemutatott intenzionális profilját is az elmúlt évtizedben ezen elv számításba vételével dolgoztuk ki, megmutatva e mondattípus helyét a hagyományosan feltételezett öt mondattípus körében.

Azonban éppen az elvégzett kísérletek eredménye arra figyelmeztet, hogy a poliszémia szigorú értelemben csupán a [h-á-t] hangsorra érvényesül(het). Működik 
a nyelvben egy olyan (ellentétes) folyamat, amelyik egyértelműsíteni igyekszik a nyelvben használt jelentéshordozó hangsorokat, például prozódiai faktorokkal, vagy eltérő mondatpozíciókban való alkalmazással (Id. 2.8.-ban a 6. táblázatot).

Miközben tehát egy-egy hangsor újabb és újabb jelentésekkel, illetve általánosabban fogalmazva újabb és újabb pragmaszemantikai kontribúciók lehetőségeivel gazdagodik (hogy újabb és újabb tartalmakat tudjunk közvetlenül leírni), az adott hangsor bizonyos jellemzői mentén elkezd differenciálódni, szigorú értelemben új nyelvi jelet létrehozva.

\section{Hát vannak még feltáratlan hát-funkciók?}

Nyilván vannak, hiszen vizsgálatunk a mondat-/fordulóindító hát-funkciókra korlátozódott, míg például a Schirm (2007-2008: 189) által alapvetőnek ítélt következtető hát (kézenfekvőnek gondolt, következményszerű gondolatok kifejezésére) eleve a mondat ige utáni pozícióját kedveli: „,??hát〉 beálltam 〈' hát〉 a sorba 〈?hát〉”. Amúgy pragmaszemantikai kontribúciójának leírása erősen emlékeztetne a határozott hát-éra (3.4.).

Még a fordulóindító hát-funkciók számba vétele sem teljes. Egyik adatközlőnk a határozott hát helyett - így neveztük el - felhorkanó hát-ot használt. Anyanyelvi intuíciónk szerint ezzel olyan jellegű felháborodást, szemrehányást érzékeltetett, amit úgy ragadhatunk meg, ha a határozott hát intenzionális profiljához hozzátesszük ezt a világocskát is:

$$
\langle\mathrm{DES}, \mathrm{M}, \mathrm{AR}, \mathrm{\tau},-\rangle \wedge\left\langle\mathrm{INT}, \mathrm{M}, \mathrm{ae}, \mathrm{\tau}^{-},+\right\rangle \wedge\langle\mathrm{INT}, \mathrm{M}, \mathrm{AR}, \mathrm{\tau},+\rangle \wedge\left\langle\mathrm{BEL}, \mathrm{M}, \mathrm{ae}, \mathrm{\tau}^{+},+\right\rangle
$$

Értelmezése: a feladó nem örül ( $(\mathrm{DES}, \mathrm{M}, \mathrm{AR}, \tau,-\rangle \wedge$...), hogy a címzettnek szándéka volt $\left(\ldots\left\langle\right.\right.$ INT, $M$, ae $\left.\left., \tau^{-},+\right\rangle \wedge \ldots\right)$ őt rávenni $(\ldots \wedge\langle$ INT, $M, A R, \tau,+\rangle \wedge \ldots)$ arra, hogy frissítse fel az adott információval az elméjét $\left(\ldots \wedge\left\langle B E L, M, a e, \tau^{+},+\right\rangle\right)-$a címzett „maga is kitalálhatta volna azt”. Az adott történetben nem érezzük jogosnak ezt a többletet, mivel Antinak nem lenne ildomos elfogult kérdéssel („Ugye a krimit választottad?") korlátoznia Bea döntési szabadságát. Adatközlőnk feltehetőleg azt akarta éreztetni a felhorkanó hát-tal, hogy nagyon nagyon kézenfekvő a döntés.

Ha a mondatindító hát kérdést vezet be, nyilván más pragmaszemantikai kontribúció jelenik meg, mint a kijelentő mondatokat indító hát-funkciók esetében (3.4.), és nem könnyű meglelni a kapcsolatot a poliszém rendszerben. Tekintsük a következő példát! „Hát beiratkoztál a szemeszterre?” Tipikusan olyankor használhatjuk ezt a mondatot, ha saját szemünkkel látjuk, hogy megtette a hallgató: itt van, beiratkozott (és valójában a valódi kérdéshangsúly helyett gyakran a Varga (1994) által hullámzónak nevezett intonációs minta jellemzi a mondatot). A továbbiakat az alábbi két világocskával ragadhatjuk meg (nem belebocsátkozva az intenzitásértékek specifikálásába): „valószínűsítem, hogy korábban nem tudtál döntésre jutni, vagy [hullámzó hangsúly esetén] elég erős szándékod volt az ellentétére; és sejtem, hogy gyanítod, hogy én ezt tudom" képlettel

$$
\begin{aligned}
& \langle B E L, g r, A R, \tau,+\rangle\left\langle\text { INT, gr, ae }, \tau^{-}, 0-\right\rangle \\
& \langle B E L, L, A R, \tau,+\rangle\left\langle B E L, l^{\prime}, \text { ae } \tau,+\right\rangle\left\langle B E L, l^{\prime}, A R, \tau,+\right\rangle\left\langle I N T, l^{\prime \prime}, \text { ae }, \tau^{-}, 0-\right\rangle
\end{aligned}
$$

Nagyon érdekes a nyelv finom differenciáló képességének a szempontjából, hogy majdnem ugyanezt jelenti a „Mégis beiratkoztál a szemeszterre?” kérdés. Ez 
esetben is annak tudatában teszi fel a kérdést a beszélő, hogy a hallgató beiratkozott, a továbbiak pedig nagyjából ezt fejezik ki: „Tudom, hogy korábban elég erős szándékod volt az ellentétére; és tudom, hogy ki is nyilvánítottad ezt a szándékot a világ felé." A képlet ezúttal így alakul:

$$
\begin{aligned}
& \langle B E L, g r, A R, \tau,+\rangle\left\langle I N T, g r, \text { ae }, \tau^{-},-\right\rangle \\
& \langle B E L, M, A R, \tau,+\rangle\left\langle I N T, M, \text { ae }, \tau^{-},+\right\rangle\left\langle B E L, M, r^{*}, \tau^{+},+\right\rangle\left\langle I N T, g r, \text { ae }, \tau^{-},-\right\rangle
\end{aligned}
$$

Mindkét esetben a 3.4. pontban tárgyalt elmeszinkronizáció motívuma sejlik fel valamilyen (közösen tudott) negatív tartalomra vonatkozóan, az utóbbi esetben explicitebben. Megjegyzésre érdemes még, hogy nem ellentét van a hát-os és a mégis-es változat között, hanem olyan befoglaló viszony, amit a két diskurzusjelölő társíthatósága is igazol: „Hát mégis beiratkoztál a szemeszterre?”

A mondatzáró nyomatékosító hát-tal kapcsolatban szeretnénk még egy érdekes megfigyeléssort közreadni. Kiegészítheti - és ezáltal nyomatékosithatja - az eldöntendő kérdésre adott választ, amennyiben az az összetett igealakból vagy az igekötőből áll. Példuál a „Kiválasztottad már a filmet?” kérdésre adhatók ilyen válaszok: „Kiválasztottam hát!”, illetve „Ki hát!”. Az „Igen” viszont nem egészíthető így ki: „”Igen hát!” További érdekesség, hogy az igekötő után a hát helyett az én is megjelenhet nyomatékosító szerepben: „'Ki én!” Különösen a meg igekötő után „hangzik jól”: „Megírtad a leckét?” - „Meg hát/én!” Azonban tagadás esetén „Megírtad a leckét?” „Nem *hát/én!” asszimetria mutatkozik a hát és a személyes névmás megítélése között.

A többi személyes névmás pedig nem jelent alternatívát a hát számára: „Megkapom a jelest?” - „Meg hát/*te!”, „Megkapja a jelest?” - „Meg hát/*?ő!”, „Megkaptuk a melót?” - „Meg hát/“mi!” Kleiber (2012) egy megjegyzése alapján a személyes névmással való nyomatékosítás többlet-eleme: valamiféle büszkesége a feladónak (és előfeltételként erős ágensi autoritás a „történtekre” vonatkozóan), ami megmagyarázza az E/1 alakhoz való ragaszkodást.

\section{Hát végre eljutottunk az összegzésig!}

Vizsgálatunkban sikerült a hát diskurzusjelölőnek elkülöníteni öt páronként szignifikánsan eltérő prozódiai jellemzőkkel bíró változatát. Ehhez a következő vokális tényezőket kellett figyelembe venni: a hát hangsor kiejtésének hosszát, az eközben változó frekvenciaértékek szórását, azaz a dallamosságot, valamint a hát-ot követő (kitöltetlen vagy kitöltött) szünet hosszát. A 2.4. szakaszban a 4. táblázat összegzi, hogy melyik pár esetében milyen tényezőknek tulajdoníthatjuk a szignifikáns elkülönülést, amennyiben konzervatív korrekciókkal szigorítva tekintjük adatainkat, számot vetve azzal, hogy sok összehasonlítás esetén annak kumulatív valószínüsége, hogy egyik esetében sem lép fel a statisztikai hiba, az elvárt küszöbérték alá süllyed.

Az említett különbség ellenére egyáltalán nem állnak ellentétben a mi eredményeink a Dér-Markó szerzőpároséival, mivel ők alapvetően fordulópozíciók szerint különítenek el funkciókat, míg a mi legfőbb állításunk az, hogy csak fordulókezdő mondatéli hát-funkcióból szignifikánsan elkülöníthető négyféle: a határozott, a bizonytalan, az aggodalmas és kétféle incselkedő; elkülönítettünk továbbá egy mondatzáró nyomatékosító hát-ot. Dér és Markó a hossz alapján a köztes pozícióban megjelenő, „késleltető” hát-ot tudja statisztikailag elkülöníteni az általuk 
vizsgált többitől (hosszabb időtartama alapján) (Dér-Markó 2017: 8-9) - amit egyébként a mi vizsgálatunk is közvetve kimutat, a következő módon. A fordulóközi „késleltető” hát a hosszú ejtést és érdemi követő-szünetet kívánó aggodalmas hátunkkal rokonítható: a „késleltetés” hátterében az a beszélői aggodalom áll, hogy az „elmeszinkronizáció” éppen nem ítélhető sikeresnek, meg kell tehát próbálni a hallgatónak másképpen elmagyarázni valamit.

Elsődleges célunk annak kísérletes igazolása volt, hogy a fordulókezdő hát az Alberti (2016) által felvetett szemaforszerű viselkedést mutatja. Azaz a három beszédhang szekvenciája önmagában nem hordoz pragmaszemantikai kontribúciót, hanem az arra illesztett prozódia üzen valami fontosat a címzettnek: „könnyen vagy nehezen emészthető vagy ... tartalomra készülj!" - a pontsor helyére írható jelzőkről a 3.4. pontban adtunk legalaposabb jellemzést, a ReALIS elmélet kínálta eszköztár segítségével, összefüggésben azzal, hogy a hát magyar szakirodalmában eddig alkalmazott leíró apparátusról kimondtuk - a téma korábbi kutatóinak véleményével összhangban -, hogy azt cizellálni érdemes egy finomabb reprezentációval. Mi amellett érvelünk, hogy olyannal, ami rekurzív leírását nyújtja a hát diskurzusjelölővel módosított megnyilatkozás feladójának az üzenetbe éppen ilyetén módon berejtett közlésébe arról, hogy milyen hipotézisei (B: belief), vágyai (D: desire) és szándékai (I: intention) vannak az üzenetbe foglalt információra nézve. Követjük viszont a Dér-Markó-szerzőpárost abban, hogy a hát-funkciókat a diskurzusjelölők multifunkcionalitásáról felállított poliszémiaelgondolás keretében célszerü megragadni (Fischer 2006: 13-14), ami azon a kézenfekvő feltételezésen alapul, hogy egyazon forma számos különböző, de egymással kapcsolatban lévő és egymásból levezethető interpretációval bír. Ez utóbbira teszünk kísérletet, mármint a jellemzett hát-funkciók kapcsolati hálózatának felállítására, egyúttal azonban finomítva/relativizálva a poliszémia-fogalmat (3.5.). A 4. szakaszban a hát további néhány funkcióját vázoltuk fel, ezzel kijelölve néhány érdekes jövőbeli kutatási témát.

A tanulmányunkban ismertetett pilot-kísérlet időközben részben betöltötte feladatát: sikerült megismételni (pontosabban egy tapasztalaink alapján tökéletesített tesztsoron újra végrehajtani) nemileg kiegyenlített 50+ „performáló” adatközlővel és immár 10 hát-funkcióval, emellett már zajlik a percepció eredményességének tesztelése. Az eddig feldolgozott adatok megerősítik az alapkísérlet kimeneteként felállítható hipotézist, miszerint az ugyanazon mondatszakaszhoz társuló hát-funkciókat döntően a hosszadatok különítik el (beleértve a követőszünet hosszát is), míg a frekvencia még a finomhangolást is csak olyan szinten „vállalja”, amit a nemszisztematikus variancia alig hagy megmutatkozni (bizonyos mértékü nemek szerinti különbséggel). Az alaphang-frekvenciából kinyerhető adatok az információszerkezet fő indikátorai - állítjuk (Szeteli-Alberti 2018) a Varga-féle mondatintonációs modellel (Varga 2016) összhangban. A közeljövőben ezt a globális képet szeretnénk kidolgozni és publikálni.

\section{Köszönetnyilvánítás}

Az elkészült tanulmányt a szerzők a Pécsi Tudományegyetem alapítása 650. évfordulója emlékének szentelik. Köszönettel tartozunk Alberti Dorinának a statisztikai próbák első sorozatának megtervezéséért és kivitelezéséért. Köszönjük továbbá a két névtelen bíráló értékes javaslatait és építő jellegű kritikai észrevételeit. 


\section{Hivatkozások}

Alberti, Gábor 2005. Accessible referents in „opaque” belief contexts. In Hans van Ditmars - Andreas Herzig (szerk.) Proc. of the 9th ESSLLI Belief Revision and Dynamic Logic Workshop. Edinburgh: University of Edinburgh. 1-7.

Alberti Gábor 2011. ReALIS: Interpretálók a világban, világok az interpretálóban. Budapest: Akadémiai Kiadó.

Alberti Gábor 2016. Hát a meg meg a hát. In Kas Bence (szerk.) „Szavad ne feledd!” Tanulmányok Bánréti Zoltán tiszteletére. Budapest: MTA Nyelvtudományi Intézet. 17-27.

Alberti, Gábor - Mónika Dóla - Judit Kleiber 2014. Mood and modality in Hungarian: Discourse Representation Theory meets Cognitive Linguistics. Argumentum 10:172-191.

Alberti, Gábor - Márton Károly 2012. Multiple level of referents in information state. In Alexander Gelbukh (szerk.) Computational Linguistics and Intelligent Text Processing. CICLing 2012. (Lecture Notes in Computer Science 7181) Berlin, Heidelberg: Springer. 349-362. doi:10.1007/978-3-642-28604-9_29.

Alberti Gábor - Kleiber Judit - Kárpáti Eszter 2017. Reális (ReALIS) kép a másik elméjéről. In Márton Miklós - Molnár Gábor - Tőzsér János (szerk.) Más elmék. Budapest: L'Harmattan Kiadó. 237-268.

Alberti, Gábor - Judit Kleiber - Zsuzsanna Schnell - Veronika Szabó 2016. Intensional profiles and different kinds of human minds. „Case studies” about Hungarian imperative-like sentence types. LingBaW (Linguistics Beyond and Within) 2:6-26.

Alberti, Gábor - László Nőthig 2015. ReALIS2.1: The implementation of generalized intensional truth tvaluation and expositive speech acts in on-going discourse. International Journal on Advances in Intelligent Systems 8/1-2:85-106.

Alberti, Gábor - Noémi Vadász - Judit Kleiber 2014. Ideal and deviant interlocutors in a formal interpretation system. In Andrzej Zuczkowski - Ramona Bongelli - llaria Riccioni - Carla Canestrari (szerk.) Communicating Certainty and Uncertainty in Medical, Supportive and Scientific Contexts. (Dialogue Studies 25) Amsterdam: John Benjamins Publishing Company. 59-78. doi:10.1075/ds.25.03alb.

Asher, Nicholas - Alex Lascarides 2003. Logics of Conversation. Cambridge: Cambridge University Press.

Austin, John Langshaw 1975 [1962]. How To Do Things With Words. Oxford: Oxford University Press.

Bell, David M. 1998. Cancellative discourse markers. A core/periphery approach. Pragmatics 8/4:515-541. doi:10.1075/prag.8.4.03bel.

Boersma, Paul 2001. Praat, a system for doing phonetics by computer. Glot International 5/9-10:341-345.

Chomsky, Noam 2013. Problems of projection. Lingua 130:33-49. doi:10.1016/j.lingua.2012.12.003.

Dér Csilla llona 2015. Diskurzusjelölök a spontán beszélt nyelvben. Kézirat. Budapest.

Dér Csilla llona - Markó Alexandra 2007. A magyar diskurzusjelölők szupraszegmentális jelöltsége. In Gecső Tamás - Sárdi Csilla (szerk.) Nyelvelmélet - nyelvhasználat. Budapest: Tinta Könyvkiadó. 61-67. 
Dér Csilla llona - Markó Alexandra 2017. A „hát” funkciói a prozódiai megvalósulás függvényében. Beszédkutatás 25:105-117. doi:10.15775/Beszkut.2017.105117.

Dowty, David R. - Robert E. Wall - Stanley Peters 1981. Introduction to Montague Semantics. (Studies in Linguistics and Philosophy 11) Dordrecht: Reidel.

Farkas, Judit - Magdolna Ohnmacht 2012. Aspect and eventuality structure in a representational rynamic semantics. In Gábor Alberti - Judit Farkas - Judit Kleiber (szerk.) Vonzásban és változásban. Pécs: PTE Nyelvtudományi Doktori Iskolája. 353-379.

Fischer, Kerstin 2006. Towards an understanding of the spectrum of approaches to discourse particles: Introduction to the volume. In Kerstin Fischer (szerk.) Approaches to Discourse Particles. Amsterdam: Elsevier. 1-20.

Gocsál Ákos 2012. A beszéd alaphangmagasságának mérése spontán beszédből és izolált [ə]-hangokból, férfi és női beszélőknél. In Markó Alexandra (szerk.) Beszédtudomány. Budapest: MTA Nyelvtudományi Intézet, ELTE Bölcsészttudományi Kar. 316-331.

Grice, H. Paul 1975. Logic and conversation. In Peter Cole - Jerry L. Morgan (szerk.) Syntax and Semantics Vol. 3. Speech Acts. New York: Academic Press. 41-58.

Kamp, Hans - Josef van Genabith - Uwe Reyle 2011. Discourse Representation Theory. In Dov M. Gabbay - Franz Guenthner (szerk.) Handbook of Philosophical Logic. Vol. 15. Berlin: Springer. 125-394.

Kleiber, Judit 2005. Across world(let)s in a representationist interpretation system. In Judit Gervain (szerk.) Proceedings of the Tenth ESSLLI Student Session. 112-121.

Kleiber Judit 2012. Keresd a szándékot! Az információállapot változása eldöntendő kérdéseknél. In Alberti Gábor - Farkas Judit - Kleiber Judit (szerk.) Vonzásban és változásban. Pécs: PTE Nyelvtudományi Doktori Iskolája. 332-352.

Kleiber, Judit - Gábor Alberti 2014. Uncertainty in polar questions and certainty in answers? In Sibilla Cantarini - Werner Abraham - Elisabeth Leiss (szerk.) Certainty-uncertainty - and the Attitudinal Space in Between. (Studies in Language Companion Series 165) Amsterdam: John Benjamins Publishing Company. 135-152. doi:10.1075/slcs.165.08kle.

Kleiber, Judit - Gábor Alberti - Veronika Szabó 2016. The intensional profiles of five hungarian imperative sentence types. Linguistica 56/1:161-172. doi:10.4312/linguistica.56.1.161-172.

Mey, Jacob L. 2001. Pragmatics: An introduction. 2nd edition. Oxford: Blackwell.

Oishi, Etsuko 2014. Discursive functions of evidentials and epistemic modals. In Sibilla Cantarini - Werner Abraham - Elisabeth Leiss (szerk.) Certaintyuncertainty - and the Attitudinal Space in Between. (Studies in Language Companion Series 165) Amsterdam: John Benjamins Publishing Company. 239-262. doi:10.1075/slcs.165.14ois.

Oishi, Etsuko 2016. Austin's Speech Acts and Mey's Pragmemes. In Keith Allan Alessandro Capone - Istvan Kecskes (szerk.) Pragmemes and Theories of Language Use. (Perspectives in Pragmatics, Philosophy \& Psychology) Berlin: Springer. 335-350. 
Schirm Anita 2007-2008. A hát diskurzusjelölő története. Nyelvtudomány IIIIV:185-201.

Schirm Anita 2011. A diskurzusjelölök funkciói: a hát, az -e és a vajon elemek története és jelenkori szinkrón státusa alapján. Doktori értekezés. Szeged: Szegedi Tudományegyetem. http://goo.gl/BXvGVU.

Schirm Anita 2017. A diskurzusjelölők vizsgálati módjai. Előadás. IX. Nyelvtudományi Szuperkurzus, 2017. január 25. Pécs.

Searle, John R. 1969. Speech Acts: An Essay in the Philosophy of Language. Cambridge: Cambridge University Press.

Searle, John R 1979. Expression and Meaning. Studies in the Theory of Speech Acts. Cambridge: Cambridge University Press.

Searle, John R. 1983. Intentionality. An Essay in the Philosophy of Mind. Cambridge: Cambridge University Press.

Szeteli, Anna - Gábor Alberti 2018. The interaction between relevant-set based operators and a topic-predicate dimension. LingBaW (Linguistics Beyond and Within) 4:161-172.

Varga László 1994. A hanglejtés. In Kiefer Ferenc (szerk.) Strukturális magyar nyelvtan 2. Fonológia. Budapest: Akadémiai Kiadó. 468-549.

Varga, László 2016. The intonation of topic and comment in the Hungarian declarative sentence. Finno-Ugric Languages and Linguistics 5/2:46-77.

\section{A szerzőkről}

Szeteli Anna pécsi egyetemi hallgató, egy OTDK II. díjjal jutalmazott pragmaszemantikai témájú dolgozat szerzője, aki a ReALIS Elméleti, Számítógépes és Kognitív Nyelvészeti Kutatócsoport tagjaként nemzetközi konferenciákon is részt vett előadással, illetve poszterrel. Biológia-kémia tanár szakos hallgatóként az etológia és az agykutatás iránti érdeklődése vitte a nyelvtudomány, és azon belül a pragmaszemantikai, a jelentéstani és a funkcionális-kognitív irányzat felé.

Elérhetösége:anna.szeteli@gmail.com.

Gocsál Ákos (PhD) egyetemi adjunktus, intézetigazgató-helyettes a Pécsi Tudományegyetem Múvészeti Karán, továbbá tudományos munkatárs az MTA Nyelvtudományi Intézetében. Kutatói érdeklődésének középpontjában a beszéd akusztikai-fonetikai tanulmányozása áll, különös tekintettel a beszélő személyre jellemző egyedi sajátosságokra. A BEA spontánbeszéd-adatbázis fejlesztésében is részt vesz (Gósy Mária vezetésével). Emellett publikál pedagógiai területen is.

Elérhetösége: gocsal.akos@pte.hu

Alberti Gábor (DSc) egyetemi tanár a Pécsi Tudományegyetemen, ahol a Nyelvtudományi Tanszéket és a Nyelvtudományi Doktori Iskolát, valamint a ReALIS Elméleti, Számítógépes és Kognitív Nyelvészeti Kutatócsoportot vezeti. Formális, lexikai és diskurzusszemantikai kutatásokon kívül a magyar nyelv generatív szintaktikai leírásában is részt vesz, jelenleg a MTA Nyelvtudományi Intézetében Kenesei István által vezetett Átfogó magyar nyelvtan (Comprehensive Grammar Resources: Hungarian) OTKA-projekt tagjaként.

Elérhetősége: alberti.gabor@pte.hu. 